\title{
Prediction of contaminant transport in fractured carbonate aquifer types: a case study of the Permian Magnesian Limestone Group (NE England, UK)
}

\author{
Giacomo Medici ${ }^{1}$ (I) $\cdot$ Landis Jared West ${ }^{1} \cdot$ Pippa Joanne Chapman ${ }^{2} \cdot$ Steven Allan Banwart ${ }^{1}$ \\ Received: 16 March 2019 /Revised: 13 May 2019 / Accepted: 17 May 2019 / Published online: 25 June 2019 \\ (C) The Author(s) 2019
}

\begin{abstract}
Viruses and bacteria which are characterized by finite lives in the subsurface are rapidly transported via fractures and cavities in fractured and karst aquifers. Here, we demonstrate how the coupling of a robust outcrop characterization and hydrogeophysical borehole testing is essential for prediction of contaminant velocities and hence wellhead protection areas. To show this, we use the dolostones of the Permian Magnesian Limestone aquifer in NE England, where we incorporated such information in a groundwater flow and particle tracking model. Within this aquifer, flow in relatively narrow (mechanical aperture of $\sim 10^{-1}$ $1 \mathrm{~mm})$ fractures is coupled with that in pipe cavities $(\sim 0.20-\mathrm{m}$ diameter) following normal faults. Karstic cavities and narrow fractures are hydraulically very different. Thus, the solutional features are represented within the model by a pipe network (which accounts for turbulence) embedded within an equivalent porous medium representing Darcian flowing fractures. Incorporation of fault conduits in a groundwater model shows that they strongly influence particle tracking results. Despite this, away from faulted areas, the effective flow porosity of the equivalent porous medium remains a crucial parameter. Here, we recommend as most appropriate a relatively low value of effective porosity $\left(\right.$ of $2.8 \times 10^{-4}$ ) based on borehole hydrogeophysical testing. This contrasts with earlier studies using particle tracking analyses on analogous carbonate aquifers, which used much higher values of effective porosity, typically $\sim 10^{2}$ times higher than our value, resulting in highly non-conservative estimates of aquifer vulnerability. Low values of effective flow porosities yield modelled flow velocities ranging from $\sim 100$ up to $\sim 500 \mathrm{~m} /$ day in un-faulted areas. However, the high fracturing density and presence of karstic cavities yield modelled flow velocities up to $\sim 9000 \mathrm{~m} /$ day in fault zones. The combination of such flow velocities along particle traces results in 400-day particle traces up to 8-km length, implying the need for large well protection areas and high aquifer vulnerability to slowly degrading contaminants.
\end{abstract}

Keywords Carbonate aquifer $\cdot$ Fracture $\cdot$ Karst $\cdot$ Contaminant transport $\cdot$ Flowing porosity $\cdot$ Normal faults

Responsible editor: Philippe Garrigues

Electronic supplementary material The online version of this article (https://doi.org/10.1007/s11356-019-05525-z) contains supplementary material, which is available to authorized users.

Giacomo Medici

g.medici@leeds.ac.uk

1 School of Earth and Environment, University of Leeds, Woodhouse Lane, Leeds, W Yorkshire LS2 9JT, UK

2 School of Geography, University of Leeds, Woodhouse Lane, Leeds, W Yorkshire LS2 9JT, UK

\section{Introduction}

Fractured carbonate aquifers, which are subjected to different degrees of karstification, underlie a land area covering $\sim 15 \%$ of the earth's surface and supply $\sim 25 \%$ of the world's population with drinking water (Hartmann et al. 2014). A range of pollutants can reach the saturated part of these aquifers in regions which are devolved to industry and agriculture, including nitrate, sulphate, chloride, toxic organic compounds released by mineral fertilizers and pesticides, and pathogens (Bales et al. 1989; Göppert and Goldscheider 2008; Mondal and Sleep 2013; Petitta et al. 2009, 2018; Reh et al. 2015; Ducci et al. 2017; Yang et al. 2017; Liu et al. 2018; Marijić et al. 2018). Animal excreta applied directly to the land from grazing animals or applied to land as farm yard manure or slurry represent a key source of nitrate, viruses, and bacteria 
(Conboy and Goss 2000; Wakida and Lerner 2005; Rivett et al. 2008).

Viruses, bacteria, and many chemical contaminants such as pesticides are characterized by specific subsurface survival times; exposure of receptors can occur where the time taken to reach supply wells or springs does not exceed these survival times and therefore depends on their velocity of transport in the subsurface (Pekdeger and Matthess 1983). Unfavourably, fast transport of these pollutants occurs in correspondence of bedding plane discontinuities, joints, and fault-related fractures rather than via porous matrix in most lithified sedimentary rocks (Hitchmough et al. 2007; Lo et al. 2014; Kocabas and Bulbul 2015; Medici et al. 2016, 2018; Jones et al. 2017). As a consequence, accurate predictions of travel time of viruses and bacteria through rock discontinuities via groundwater flow and contaminant transport models are needed in order to define groundwater source protection areas around springs and abstraction boreholes (Taylor et al. 2004; Riva et al. 2005; Bagherzadeh et al. 2018). The delineation of source protection areas and/or well capture zones allows regulators to restrict land use and activities such as manure spreading to avoid impacts on sources.

In this paper, we show how the coupling of robust characterization of rock discontinuities in an outcrop and hydrogeophysical borehole testing makes a large difference in the prediction of contaminant transport velocities and therefore the vulnerability of borehole abstraction points to pollution. We also provide guidelines on how to better predict transport in dolomitic limestone environments using both appropriate values of flowing porosity in un-faulted areas and a flow regime in correspondence of normal faults. Although these are key aspects of management of carbonate aquifers, geo-modellers in industry, research institutes, and universities typically treat fault hydraulics and flowing porosity in a nonrigorous way. Indeed, prediction of contaminant transport using codes such as MODPATH requires specification of the effective flowing porosity to define source protection areas (Pollock 2016). Values assigned to this parameter range from $\sim 10^{-3}$ to $10^{-1}$ in fractured carbonate aquifers with a typical value of $5.0 \times 10^{-2}$ which is assigned by modellers without evidence from hydrogeophysical tests (Neymeyer et al. 2007; Bredehoeft and King 2010; Worthington et al. 2012; Yager et al. 2013; Zuffianò et al. 2016; Gárfias et al. 2018). In contrast, the combination of an acoustic televiewer and fluid logging with hydraulic conductivity from falling or rising head tests shows much lower values $\left(\sim 10^{-4}\right)$ of effective porosity in fractured rocks (Quinn et al. 2011; Ren et al. 2018). Values of effective porosity in the same order of magnitude have been found by Maldaner et al. (2018) in a fractured dolostone combining an acoustic televiewer and well dilution tests with falling and rising head and pumping test data. Similar results were obtained for our case study aquifer by Medici et al. (2019a) in the fractured dolomitic limestones of the UK Magnesian
Limestone aquifer which is the subject of this paper. In this paper, we test the sensitivity of contaminant transport to flowing porosity values assumed for this aquifer.

Faulted areas in limestone environments typically show high values of transmissivities, and springs often emerge from associated systems of conduits or caves (Allen et al. 1997; Amoruso et al. 2013; Maurice et al. 2016; Bauer et al. 2016). As a consequence, several authors highlight the need to model turbulent flow in correspondence of faults in karst environments (Bauer et al. 2003; Hill et al. 2010; Gallegos et al. 2013; Saller et al. 2013). Faults in high mechanically $\left(\mathrm{UCS}_{\text {nat }}>45 \mathrm{MPa}\right)$ resistant carbonate rocks are characterized by either non-intensively karstified fractures or karstic cavities (Billi et al. 2007; Lott 2013; Bauer et al. 2016). Flow can be Darcian in correspondence of relatively closed fault-related fractures (Berkowitz et al. 1988; Berkowitz 2002). However, cavities in correspondence of normal faults can approximate pipes in which turbulence arises (Worthington and Ford 2009; Hill et al. 2010; Gallegos et al. 2013; Saller et al. 2013). To account for this, in this paper, we model both Darcian and non-Darcian (turbulent) flow in fault zones using the available MODFLOW-2005 numerical codes.

Scientific literature on the physical hydrogeology of the Magnesian Limestone aquifer in Great Britain has focused on core plug and pumping test analyses (Aldrick 1978; Cairney 1972; Allen et al. 1997). More recently, Medici et al. (2019a) combined optical and televiewer logging, monitoring of the water table, slug tests, and temperature and electrical conductivity fluid logs to compute groundwater flow velocities in the area of this study in Yorkshire, UK (Fig. 1a, b). Time series data show minimal seasonal variation of groundwater flow velocities and direction (Medici et al. 2019a). As a consequence, steady-state flow models can adequately represent the flow velocity field. Previous published geochemical data are limited to analyses of major anions and cations in the Magnesian Limestone aquifer in the County Durham area, UK (Crabtree and Trudgill 1984; Younger 1995; Mayes et al. 2005). In this paper, baseline hydrochemical analyses that provide data on $\mathrm{pCO}_{2}$ and saturation indexes of calcite, dolomite, and aragonite for the area of this study (Fig. 1a, b) are also presented. Our purpose is to provide useful information on drivers of karst development in correspondence of rock discontinuities (bedding planes, joints, and faults) which represented the focus of the flow modelling in this research.

The overall aim of this paper is to improve the prediction of contaminant transport in fractured carbonate aquifers showing karst development, based on the incorporation of outcrop and borehole hydrogeophysical data within groundwater flow and particle tracking models. The specific objectives of the presented research are (i) to establish a link between hydrochemistry and karstification in the Magnesian Limestone aquifer, (ii) to achieve a reliable groundwater flow 

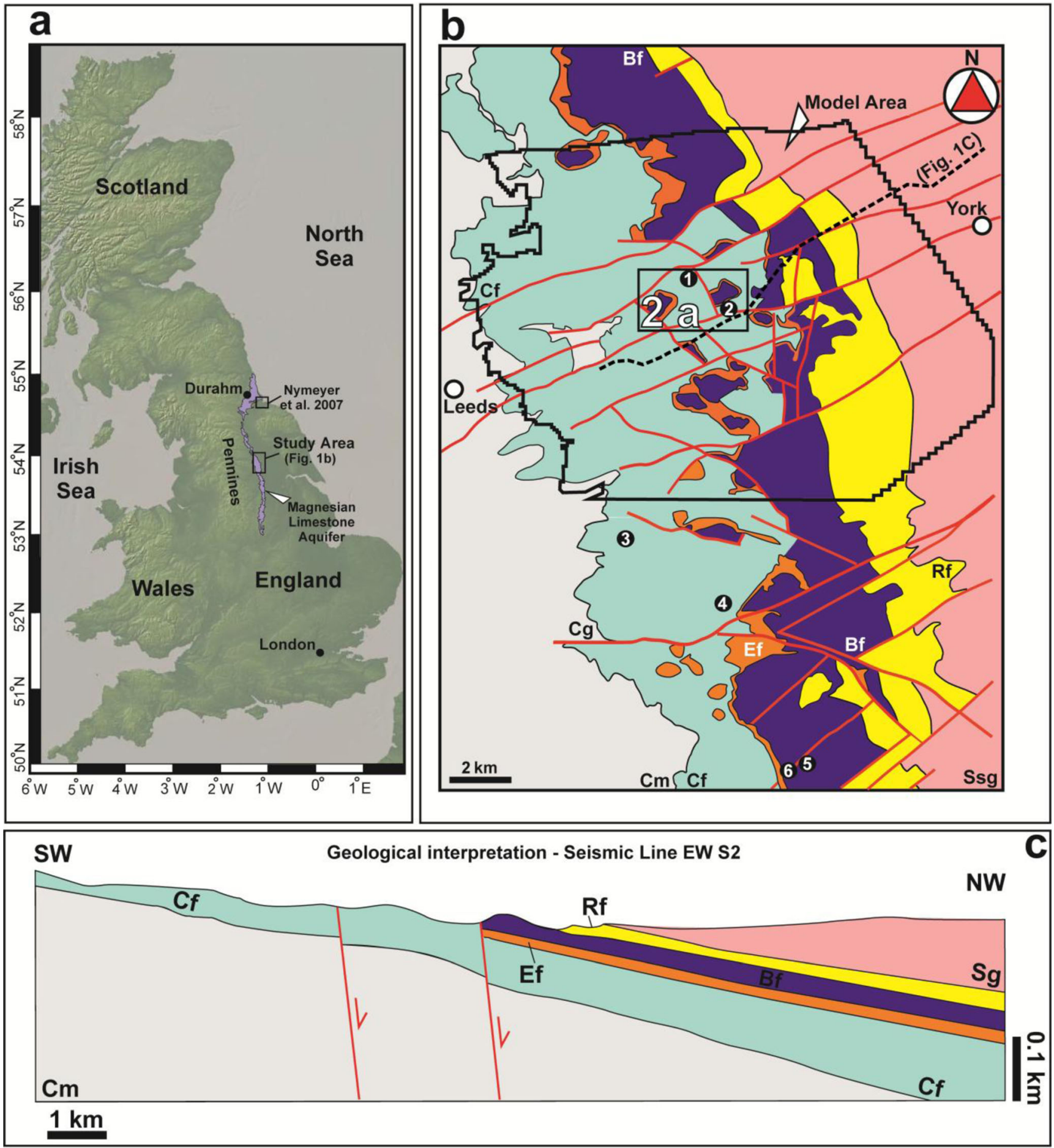

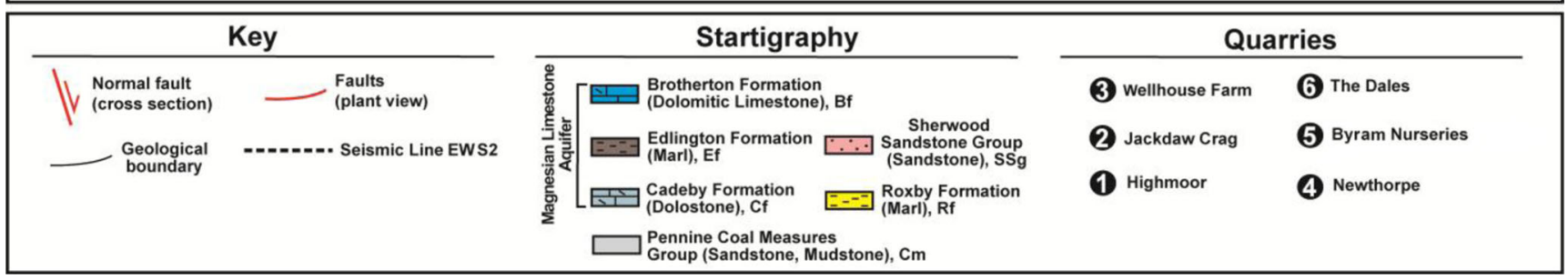


4 Fig. 1 Study area. a Map describing the Magnesian Limestone aquifer in Great Britain and the location of the study area (basemap from GeoMapApp) and that of a previous study by Neymeyer et al. (2007). b Geological map with the location of the numerical groundwater flow model area (thick black line) and the University of Leeds farm site for hydrogeophysical characterization (boxed area, see the enlarged view in Fig. 2) and discontinuity surveys (numbers) and the location of the cross section shown in $\mathbf{c}$ (dashed line). $\mathbf{c}$ The geological cross section EW-S2 based on a seismic line (Cooper and Lawley 2007)

model that accounts for outcrop and hydrogeophysical constraints on the key flow pathways, (iii) to identify the most appropriate parameters and approaches for particle tracking both away from and around faults, and (iv) to identify the key structural and hydraulic factors that influence contaminant transport.

\section{Study area}

\section{Geological background}

The study area (see Fig. 1a-c) is located in Yorkshire (NE England, UK) between the cities of Leeds and York. This area includes both the site of detailed hydrogeophysical characterization undertaken by Medici et al. (2019a) and that of the flow model developed in this paper (Figs. 1b and 2a). The Magnesian Limestone Group is formed by dolomitic limestone, dolostone, and evaporite rocks derived from sedimentation in the marginal areas of the Permian Zechstein Basin (Harwood 1986; Smith et al. 1986). In Yorkshire, the Magnesian Limestone aquifer was deposited during the Lower Permian under subtropical and tropical conditions. The Magnesian Limestone Group is formally part of the Zechstein Group in NE England (Harwood 1986). Here, this group is characterized by three geological formations: the Cadeby, Edlington, and Brotherton formations (Fig. 1b; Smith et al. 1986).

The Cadeby and Brotherton formations are carbonate units; they are separated by the anhydrite and gypsum strata of the Edlington Formation (Fig. 1b). The basal part of the Cadeby Formation is characterized by a 5-m-thick marl interval which separates the geological formation from the marly sandstones and clays of the Pennine Coal Measures Group (Fig. 1b, c). The Brotherton Formation passes upwards into the Roxby Formation which represents an aquiclude formed by anhydrite, gypsum, and mudstone (Cooper 1988).

The Cadeby Formation is dominated by wackstones, packstones, and grainstones showing ooids, corals, and bivalves in a thin section (Kaldi 1986). This formation was deposited during the Lower Permian (272-251 Ma) in a shallow marine environment. Then, secondary dolomitization occurred during the early Permian and middle Triassic time (Harwood 1986; Kaldi 1986; Peryt and Scholle 1996). Dolomitization fluids likely originated from the gypsum, anhydrite, and halite of the overlying Edlington Formation (Harwood and Coleman 1983; Harwood 1986). The Brotherton Formation above represents the uppermost unit of the Magnesian Limestone aquifer in Great Britain and is formed by thin dolomitic limestone beds with ooids, peloids, photosynthetic algae, and micro- and macro-foraminifera. The wackstones, packstones, and grainstones of the Brotherton Formation were also deposited in a shallow water environment, but they differ from those of the Cadeby Formation due to less intense dolomitization (Harwood 1986; Peryt and Scholle 1996). Indeed, the Cadeby Formation $\left(54 \% \mathrm{CaCO}_{3}\right.$, $46 \% \mathrm{MgCO}_{3}$ ) is less abundant in calcite with respect to the Brotherton Formation $\left(54 \% \mathrm{CaCO}_{3}, 46 \% \mathrm{MgCO}_{3}\right)$ in $\mathrm{NE}$ England (Kaldi 1986; Lott and Cooper 2005).

In Yorkshire, in the area of study (Fig. 1b, c), the tectonic features which deform the UK Magnesian Limestone aquifer are extensional faults and non-stratabound joints (sensu Odling et al. 1999). Quarry observations and seismic reflection surveys carried out in the Leeds-York area show how extensional faults of the Mesozoic age are mainly oriented ENE-WSW (Fig. 1b; Walsh and Watterson 1988; Cooper and Lawley 2007). The absence of major normal faults oriented parallel to the Pennine structures in NE England is due to lack or limited extension related to the Permo-Mesozoic opening of the Atlantic Ocean (Hallam 1971; Burley 1984; Medici et al. 2015, 2019b). Lack of significant effects of the Cenozoic Alpine orogenesis results in the gentle dip $\left(<5^{\circ}\right.$ towards E) of the Permo-Mesozoic deposits in the Yorkshire area (Fig. 1b, c; Bottrell et al. 2006; West and Truss 2006; West and Odling 2007; Keim et al. 2012: Medici et al. 2019a). The Magnesian Limestone aquifer varies in thickness from 70 to $110 \mathrm{~m}$ towards the east (see Fig. 1c). This is due to the shelf-edge geometry of the Permo-Triassic basin in the study area which overlaps on the Carboniferous strata further west (Cooper and Lawley 2007; Medici et al. 2015).

Field observations at quarries in the Cadeby and Brotherton formations show how normal faults are characterized by zones of deformation up to $\sim 30 \mathrm{~m}$ wide in sections parallel to the dip (Aldrick 1978; Allen et al. 1997). However, boreholes drilled in non-faulted sections show high angle joints (dip 50-80 ) which cross-cut the bedding parallel fractures (Medici et al. 2019a). Such high angle joints have been previously studied in the Magnesian Limestone aquifer in County Durham (Kortas and Younger 2013) as well as in other aquifers of the PermoMesozoic age across Great Britain (Allen et al. 1997, 1998; Hitchmough et al. 2007; Medici et al. 2016, 2018). These fractures arise from the Cenozoic uplift of NW Europe and are related to unloading due to removal of overlying beds (Odling et al. 1999; Gillespie et al. 2001; Kortas and Younger 2013). Other discontinuities present in the Magnesian Limestone are subhorizontal bedding plane fractures and stylolites. Bedding plane fractures in this aquifer originate from movements associated with the Cenozoic uplift (Kortas and Younger 2013). Stylolites are solution features that formed during burial 
Fig. 2 University of Leeds experimental farm site showing the location and elevation of the three drilled boreholes where monitoring/hydrogeophysical characterization was undertaken in 2017/18. a Geological map and location of boreholes (see Fig. 1 for legend). b Geometry of BH1, $\mathrm{BH} 2$, and $\mathrm{BH} 3$ piezometer installations
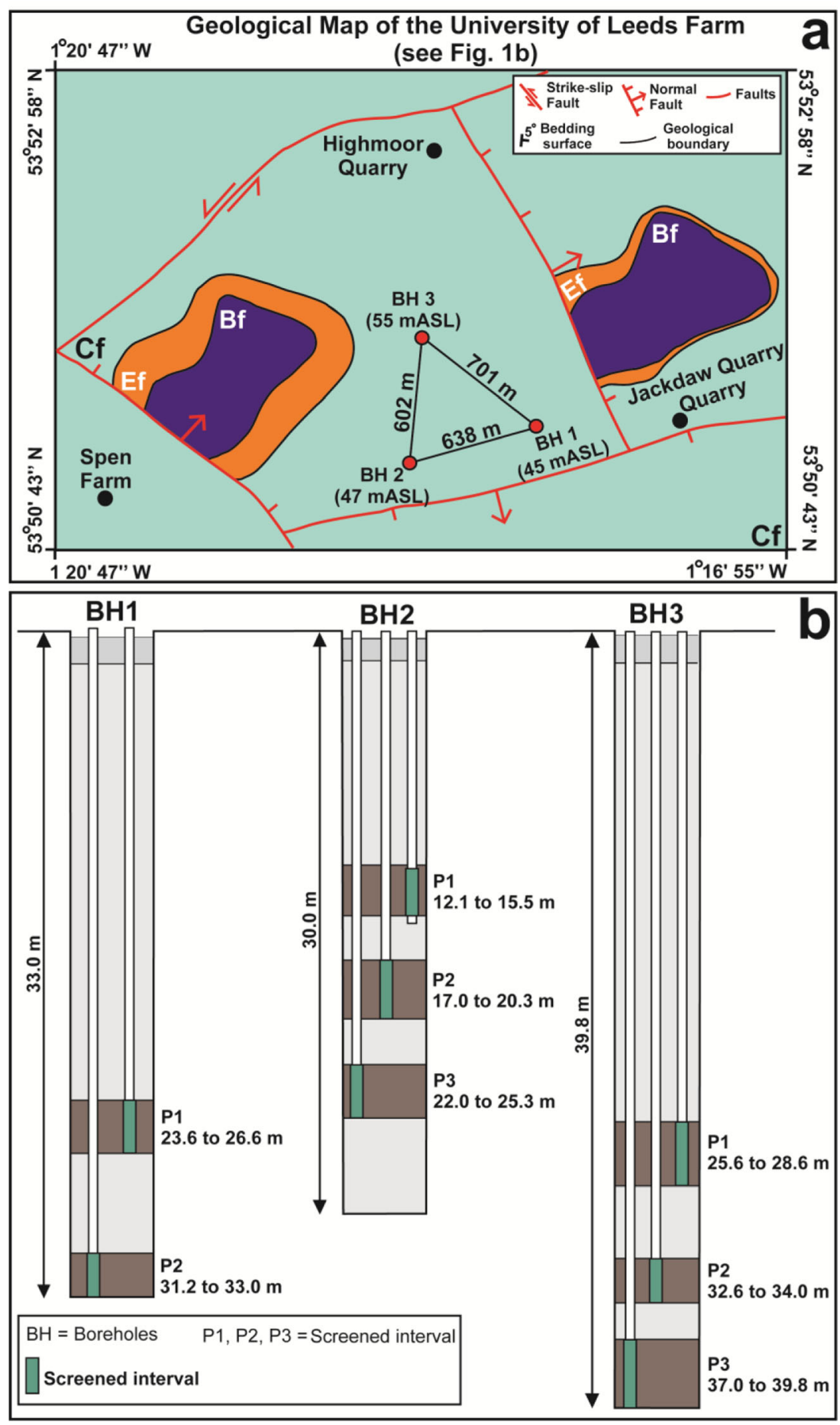

diagenesis under the effect of the lithostatic pressure (Railsback, 1983; Tondi et al. 2006).

\section{Hydrogeological setting}

The Magnesian Limestone aquifer represents the fifth most important aquifer for volumes of water withdrawn in Great Britain (Younger 1995; Edmunds et al. 2003; Rivett et al.
2007; Abesser and Lewis 2015). Contamination in this dolomitic aquifer is related to the application of fertilizers to agricultural fields. Indeed, nitrate concentrations steadily increased after the Second World War from an average of $0.30 \mathrm{mg} \mathrm{L}^{-1}$ in 1945 to $80 \mathrm{mg} \mathrm{L}^{-1}$ in 2005 in the study area (Aldrick 1978; Walker 2006). The Magnesian Limestone aquifer is unconfined in the western part of the area due to the absence or presence of only $\sim 1$-m-thick superficial cover 
consisting of sands and clays of the Quaternary age (Fig. 1b; Gaunt et al. 1970; Allen et al. 1997). The aquifer becomes confined in the eastern part of the groundwater flow model area (Fig. 1b), i.e., resulting from gentle dip towards the east (see Fig. 1c). The Cadeby and Brotherton formations represent dolomitic, relatively permeable units, which are separated by the marls and evaporates of the Edlington Formation. The latter formation is considered a leaky aquitard; i.e., dissolution of anhydrite and gypsum beds only gives very limited permeability (Farrant and Cooper 2008). Boreholes with piezometers installed in both the Cadeby and Brotherton formations show head differences ranging from 0.25 up to $2.00 \mathrm{~m}$ in some areas of NE England (Aldrick 1978; Allen et al. 1997). However, some hydraulic connectivity between the Cadeby and Brotherton formations arises from normal faulting (Farrant and Cooper 2008). The Magnesian Limestone aquifer is highly mechanically resistant (UCS of 48-75 MPa), and thus it appears to be heavily fractured at quarry sites (Lott and Richardson 1997; Cooper and Lawley 2007; Lott 2013).

Groundwater flow is directed towards the east driven by topography which is characterized by the topographic high of the Pennines to the west (Fig. 1a). The Cadeby Formation interquartile interval ranges for porosity and core plug hydraulic are 8.5 to $18.7 \%$ and $2.9 \times 10^{-4}$ to $0.9 \times 10^{-3}$, respectively. These interquartile intervals largely overlap those of the Brotherton Formation, which are 9.9-19.0\% and $4.0 \times 10^{-4}-1.5 \times 10^{-3} \mathrm{~m} /$ day for porosity and core plug scale hydraulic conductivity, respectively (Allen et al. 1997).

Slug tests in the Cadeby Formation of the UK Magnesian Limestone show hydraulic conductivities ranging from 0.07 up to $2.89 \mathrm{~m} /$ day. Notably, higher values of hydraulic conductivities $(K=0.83-2.89 \mathrm{~m} /$ day $)$ from these tests characterize the first $15 \mathrm{~m}$ below the water table (Medici et al. 2019a). Singleborehole pumping test values from the Magnesian Limestone aquifer of Great Britain range from 6 to $300 \mathrm{~m}^{2} /$ day with a median of $25 \mathrm{~m}^{2} /$ day in un-faulted areas (Cairney 1972; Allen et al. 1997).

Assuming a 15-m effective thickness for the Cadeby Formation in the model area (Fig. 1b), hydraulic conductivity ranges from 0.8 to $10 \mathrm{~m} /$ day with median values of $1.3 \mathrm{~m} /$ day in un-faulted areas; the hydraulic conductivity of the Cadeby Formation $\left(K_{\text {median }}=1.2 \mathrm{~m} /\right.$ day, $\left.n=16\right)$ is lower with respect to that of the Brotherton Formation $\left(K_{\text {median }}=2.7 \mathrm{~m} /\right.$ day, $\left.n=15\right)$ (Medici et al. 2019a). This has been considered a consequence of the higher dolomitization which characterizes the Cadeby Formation; this reduces the rate of mineral dissolution along rock discontinuities. By contrast, the dolomitic limestone of the Brotherton Formation is more abundant in calcite; thus, dissolution and development of permeable flow pathways are favoured (Cooper and Lawley 2007; Farrant and Cooper 2008).

The highest transmissivity $\left(T_{\text {median }}=2000 \mathrm{~m}^{2} /\right.$ day; $\left.n=7\right)$ values in the Magnesian Limestone in both the Cadeby and
Brotherton formations are related to extensional faults (Aldrick 1978; Allen et al. 1997; Cooper and Lawley 2007; Neymeyer et al. 2007). Springs emerge in correspondence of faults at the study site between the cities of Leeds and York (Aldrick 1978). Groundwater flow is largely dominated by fractures. This is shown by a four-order magnitude difference between hydraulic conductivity from well and core plug tests ( $K_{\text {well-test }} / K_{\text {core-plug }} \sim 10^{4}$; Allen et al. 1997). Groundwater in the Cadeby Formation in the northern area of Durham (Fig. 1a) is highly alkaline $\left(380-450 \mathrm{mg} \mathrm{L}^{-1}\right)$, due to chloride and sulphate dissolution from the anhydrite and halite of the Edlington Formation above (Mayes et al. 2005).

\section{Material and methods}

\section{Scanlines}

Horizontal and vertical scanline surveys have been carried out at six quarry outcrops around the Leeds-York area in Yorkshire (see Fig. 1a, b) to characterize the fracture network of the Magnesian Limestone Group in faulted and un-faulted sections. The selected method (Hitchmough et al. 2007) consists in the recording of 7 parameters in an outcrop: strike orientation, dip inclination, fracture spacing, percentage of infilled fractures, fracture trace persistence, and mechanical aperture. Overall, 401 discontinuities were recorded and divided into 6 groups (D1-6): bedding planes (D1, $n=114$ ), stylolites (D2, $n=25)$, south (D3, $n=67)$ and north (D4, $n=90$ ) dipping subvertical joints, and south (D5, $n=60)$ and north (D6, $n=45)$ dipping fault-related fractures. Rock discontinuities were plotted on stereonets, and mean vector statistics of each group computed with the Stereonet software package (Allimendinger et al. 2012).

\section{Physiochemical analyses}

Physical and geochemical parameters of groundwater have been assessed in three boreholes (BH1, BH2, and $\mathrm{BH} 3$ ) drilled at the University of Leeds farm (Fig. 1b, c). Here, groundwater sampling for physiochemical analyses has occurred on six occasions during 2018.

Temperature, conductivity, $\mathrm{pH}$, and alkalinity were recorded in the field on samples collected from each screened interval (see Fig. 2a, b) of the three boreholes using a discrete interval bailer (425 LDPE Solinst). Temperature and $\mathrm{pH}$ were measured using 6PFCE Ultrameter II (Myron L Company); electrical conductivity and alkalinity (i.e., bicarbonate $\mathrm{HCO}_{3}{ }^{-}$) were measured using a 9033 Multi-Range Electrical Conductivity Meter (Hanna Instruments) and Digital Titrator Model 16900' (Hach Company), respectively. Calibration of probes was carried out at the beginning of each day of field work, and maintenance of calibration was checked prior to each measurement. Groundwater samples were filtered through a $0.25-\mu \mathrm{m}$ pore 
membrane into a 50-mL bottle in the field using a syringe; a few drops of $10 \%$ nitric acid were added to the $50-\mathrm{mL}$ bottles for preservation of cations. Samples were preserved at $4{ }^{\circ} \mathrm{C}$ in the fridge prior to laboratory analyses (Piper 1953). Major anions $\left(\mathrm{Cl}^{-}, \mathrm{SO}_{4}{ }^{2-}, \mathrm{NO}_{3}{ }^{-}\right)$and cations $\left(\mathrm{Na}^{+}, \mathrm{Mg}^{2+}, \mathrm{K}^{+}, \mathrm{Ca}^{2+}, \mathrm{Mn}^{2+}\right.$, $\mathrm{Fe}^{2+}, \mathrm{Al}^{3+}$ ) were determined in the laboratory using an іСАРтм 7600 ICP-OES and ICS-3000 Ion Chromatographer (both Thermo Scientific Ltd.), respectively. Charge balance errors were calculated and range from 0.1 up to $3.8 \%$, which suggests goodquality data. Dissolved organic carbon (DOC) was calculated from the difference between total dissolved carbon (DC) and dissolved inorganic carbon (DIC), which were both measured by a Multi N/C 2100 Analyser (Analytik Jena).

PHREEQC 3.4.0 Interactive (Parkhurst and Appelo 1999) was used to calculate the partial pressure of carbon dioxide $\left(\mathrm{pCO}_{2}\right)$ and saturation indexes (SI) for calcite, aragonite, and dolomite.

\section{Groundwater flow model}

A steady-state groundwater flow model of the Magnesian Limestone aquifer was developed for the Leeds-York area of NE England (Fig. 1b) by the Environment Agency using MODFLOW-2005 (Environment Agency 2009). In this study, this model was modified to take account of the hydrogeophysical data on the effective aquifer thickness of the Cadeby Formation, which is much less than its full thickness (Medici et al. 2019a), and karst development in the UK Magnesian Limestone associated with faults.

The Environment Agency (2009) steady-state flow model was calibrated using hydraulic conductivity and river bed conductance. This model simulates steady-state flow conditions from 1 February 2004 to 31 December 2008, using hydraulic heads measured by the Environment Agency from 47 observation boreholes within the Cadeby Formation (Fig. 8c).

The 3D groundwater flow model is characterized by three layers which represented the Cadeby (lowest, layer 1), Edlington (layer 2), and Brotherton (uppermost, layer 3 ) formations of the UK Magnesian Limestone, respectively.

External boundary conditions are the same in layers 1 and 2 of the Environment Agency (2009) steady-state flow model for the northern, southern, and western edges. The northern edge is a noflow boundary, as the drainage network indicates a groundwater divide. The southern boundary is treated as a general head boundary due to the continuation of the Magnesian Limestone aquifers beyond the modelled domain here and the absence of a groundwater divide. The western edge of the steady-state groundwater flow model is also considered a general head boundary to account for cross-boundary flow with the underlying Carboniferous strata (see Fig. 1b). The eastern edge is defined as a no-flow boundary for the Cadeby (layer 1) and Edlington (layer 2) formations which lie within the deeply confined part of the aquifer beneath the Roxby Formation (Upper Permian Marl, see
Fig. 1b), so flow is likely to be negligible. However, the uppermost Brotherton Formation (layer 3 ) in the eastern edge is represented as a general head boundary to represent flow to/from the Sherwood Sandstone Group through the Roxby Formation (see the geological structure in Fig. 1b, c).

Rainfall recharge is applied to the uppermost layer in the model at any given location and was calculated from four sources: precipitation and evapotranspiration data, a map of Quaternary deposits, and soil type (Environment Agency 2009). Note that hydraulic head data and boundary conditions are unchanged in the new version of the groundwater flow model described below.

New analysis of rock discontinuities coupled with previous geomorphological observations (Murphy 2000; Cooper and Lawley 2007) was also used to modify the Environment Agency (2009) model. The Conduit Flow Process Mode 1 (CFPM-1) pipe flow framework developed by Hill et al. (2010) for MODFLOW-2005 was inserted, due to the presence of faults, to model turbulence in conduits observed in outcropping fault zones. A CFPM-1 pipe network composed of 1317 nodes was created following the recommendations of the United States Geological Survey (USGS) (Gallegos et al. 2013; Saller et al. 2013). Rates of laminar $\left(Q_{1}\right)$ and turbulent $\left(Q_{t}\right)$ flow for the pipes are described by Eqs. (1) and (2), respectively (Hill et al. 2010; Saller et al. 2013):

$$
\begin{aligned}
& Q_{1}=-\frac{d^{4} \pi g \Delta h}{128 v \Delta l \tau} \\
& Q_{t}=-\frac{\Delta h}{|\Delta h|} \sqrt{\frac{|\Delta h| g d^{5} \pi^{2}}{2 \Delta l \tau}} \log \frac{2.5 v \Delta l}{\sqrt[4]{\frac{2|\Delta h| g d^{3}}{\Delta l \tau}}}+\frac{r}{3.71 d}
\end{aligned}
$$

In the previous equations, $d(\mathrm{~L})$ is the pipe diameter, $\tau(-)$ is the pipe tortuosity, $r(\mathrm{~L})$ is the average micro-topography (or asperity height) of the pipe walls, $\nu\left(\mathrm{L}^{2} \mathrm{~T}^{-1}\right)$ is the kinematic viscosity, $g\left(\mathrm{LT}^{-2}\right)$ is the gravitational acceleration constant, $\Delta l$ (L) is the pipe length, and $\Delta h(\mathrm{~L})$ is the hydraulic head loss along the pipe. $\Delta l$ is $100 \mathrm{~m}$ equal to the length of a cell. The diameter (d) of the pipes in the network has been assigned by model calibration. Pipe tortuosity has been assigned a value of 1.3 based on quarry outcrop observations (Boddy 2018; Walker 2006). Kinematic viscosity of water was assigned a value of $1.31 \times$ $10^{-6} \mathrm{~m}^{2} \mathrm{~s}^{-1}$, based on the annual average water temperature of $10{ }^{\circ} \mathrm{C}$ in boreholes with seasonal variation $<1.5^{\circ} \mathrm{C}$ (Environment Agency 2009). The average micro-topography $\left(r=1.8 \times 10^{-3} \mathrm{~m}\right)$ of the pipe walls is known from previous measurements on rock samples from quarries in the area (Boddy 2018).

\section{Particle tracking analysis}

Abstraction well capture zone analysis was carried out using the MODPATH particle tracking code (Pollock 2016). 
Backward particle tracking analysis is run for 100 particles from the 4 abstraction boreholes. The MODPATH code uses the cell-by-cell flow terms that are created by the MODFLOW-2005 simulation to determine backward particle movement directions and rates, along with the effective flow porosity.

The MODPATH code has been applied to the new groundwater flow model which was produced implementing the preexisting model (Environment Agency 2009). Effective flow porosity value was set to either $2.8 \times 10^{-4}$ or $5.0 \times 10^{-2}$ which are values for UK Magnesian Limestone. The value of $2.8 \times$ $10^{-4}$ was determined from well acoustic and fluid logging combined with slug tests by Medici et al. (2019a) at the University of Leeds farm site within the modelled area (Figs. $1 \mathrm{~b}$ and 2a). The much higher value of $5.0 \times 10^{-2}$ was used in particle tracing modelling of the County Durham Magnesian Limestone by Neymeyer et al. (2007). This is a standard value from the literature for such aquifer types (Bredehoeft and King 2010; Zuffianò et al. 2016; Gárfias et al. 2018).

For each effective flow porosity, particle traces have been found for two different travel times of 50 and 400 days. These two travel time values are based on short- and long-lived pathogens in groundwater for definition of wellhead protection areas (Taylor et al. 2004). Note that particle tracking analysis exclusively involves the Cadeby Formation due to the position of the abstraction wells.

\section{New characterization of the Magnesian Limestone aquifer}

\section{Fracturing network}

Visual observations of karst features and discontinuity surveys (scanlines along both horizontal and vertical directions) have been performed in quarries (see Fig. $1 \mathrm{~b}$ for locations, Figs. 3a$\mathrm{d}$ for photos, and Table 1 and Figs. 4 and S1 for scanline results) in the Cadeby (Jackdaw, Highmoor, Newthorpe, Wellhouse Farm, and Byram Nurseries quarries) and the Brotherton (Byram Nurseries and the Dales quarries) formations of the Magnesian Limestone Group.

The fracturing network in un-faulted sections has been studied at Jackdaw Crag, Highmoor, Newthorpe, Wellhouse Farm, and Byram Nurseries quarries. Normal faults are not mapped (Fig. 1b) in Highmoor, Newthorpe, and Wellhouse Farm quarries, and they have not been detected in our surveys there. Although normal faults outcrop at Jackdaw Quarry, such structures have been avoided, i.e., poor exposure of these tectonic structures. Scanline surveys have been performed both on un-faulted (Bh1, Bv) and faulted (Bh2) rock faces at the Byram Nurseries quarry (see Table 1). Scanline surveys (Dh1, Dh2, Dv) were performed in correspondence of a normal fault at the Dales quarry (see Fig. $1 \mathrm{~b}$ and Table 1).
Discontinuities were subdivided into six different sets (Fig. 4b). Bedding planes (D1) and stylolites (D2) which are subhorizontal $\left(<5^{\circ}\right)$ are related to the sedimentary structure of the Magnesian Limestone Group. Open bedding plane (D1) discontinuities represent either bedding planes enlarged by groundwater dissolution or mechanically reactivated fractures which are due to the Cenozoic uplift of Great Britain (Kortas and Younger 2013).

Stylolites (D2) are pressure solution structures which are characterized by more irregular shape with respect to the bedding plane (D1) discontinuities (see Fig. 3b). Stylolite (Fisher mean vector $=105^{\circ}-3.1^{\circ}$ ) and bedding plane (Fisher mean $=44^{\circ}-$ $3.8^{\circ}$ ) dip directions are consistent with the regional dip towards the northeast or east (Figs. 1c, 4a-c, and S1).

South (D3) and north (D4) dipping high angle (55 to $90^{\circ}$ ) joints are interpreted as related to the Cenozoic uplift of NW Europe in the Magnesian Limestone Group (Kortas and Younger 2013). However, fractures dipping towards south (D5) and north (D6) are related to the extensional faults outcropping at the Dales and the Byram Nurseries quarries (Fig. 1b). Plotting of fault-related (D3, D4) and non-fault-related (D5, D6) discontinuities shows how both are E-W striking (Figs. 4 and $\mathrm{S} 1$ ).

The average vertical spacing of bedding plane (D1) discontinuities is $0.20 \mathrm{~m}$ (Fig. 3a); the average persistence of nonfault-related subvertical joints (D3, D4) is $0.66 \mathrm{~m}$ (Table 2). Subvertical joint persistence exceeds vertical spacing of bedding fractures. Thus, bedding plane fractures (D1) and subvertical joints (D3, D4) collectively form a nonstratabound fracturing network. Fault-related fractures (D5, D6) are similar to the non-stratabound joints (D3, D4) in terms of persistence (see Table 2). However, the fault zones outcropping at the Dales and Byram Nurseries quarries are characterized by a higher density of such joints with respect to unfaulted sections in the Magnesian Limestone Group (see Table 1). The average spacing of fractures in a fault zone is 0.04 and $0.11 \mathrm{~m}$ along the vertical and horizontal directions, respectively. This contrasts with non-faulted sections which are characterized by higher average vertical $(0.05 \mathrm{~m})$ and horizontal $(0.17 \mathrm{~m})$ spacing (Table 1). Fault-related fractures (D5, D6) also differ from the non-stratabound fracturing in that they have much higher fracture aperture (Table 2). The average aperture $(a)$ is $1.6 \mathrm{~mm}$ in the fault zones of the Dales and Byram Nurseries quarries. Here, some apertures in correspondence of faults range from 0.10 up $0.6 \mathrm{~m}$ (see cavities in Fig. $3 \mathrm{c}, \mathrm{d})$. Cavities show a range of cross sections in an outcrop from circular and tabular to polygonal with smoothed angles. Although such cavities are likely enlarged by groundwater dissolution, note that $58 \%$ of discontinuities in faulted zones nevertheless show apertures $<1 \mathrm{~mm}$. Away from faults, the average aperture is $0.7,0.6$, and $0.3 \mathrm{~mm}$ for non-stratabound joints (D3, D4) and bedding planes (D1), respectively (Table 2). 

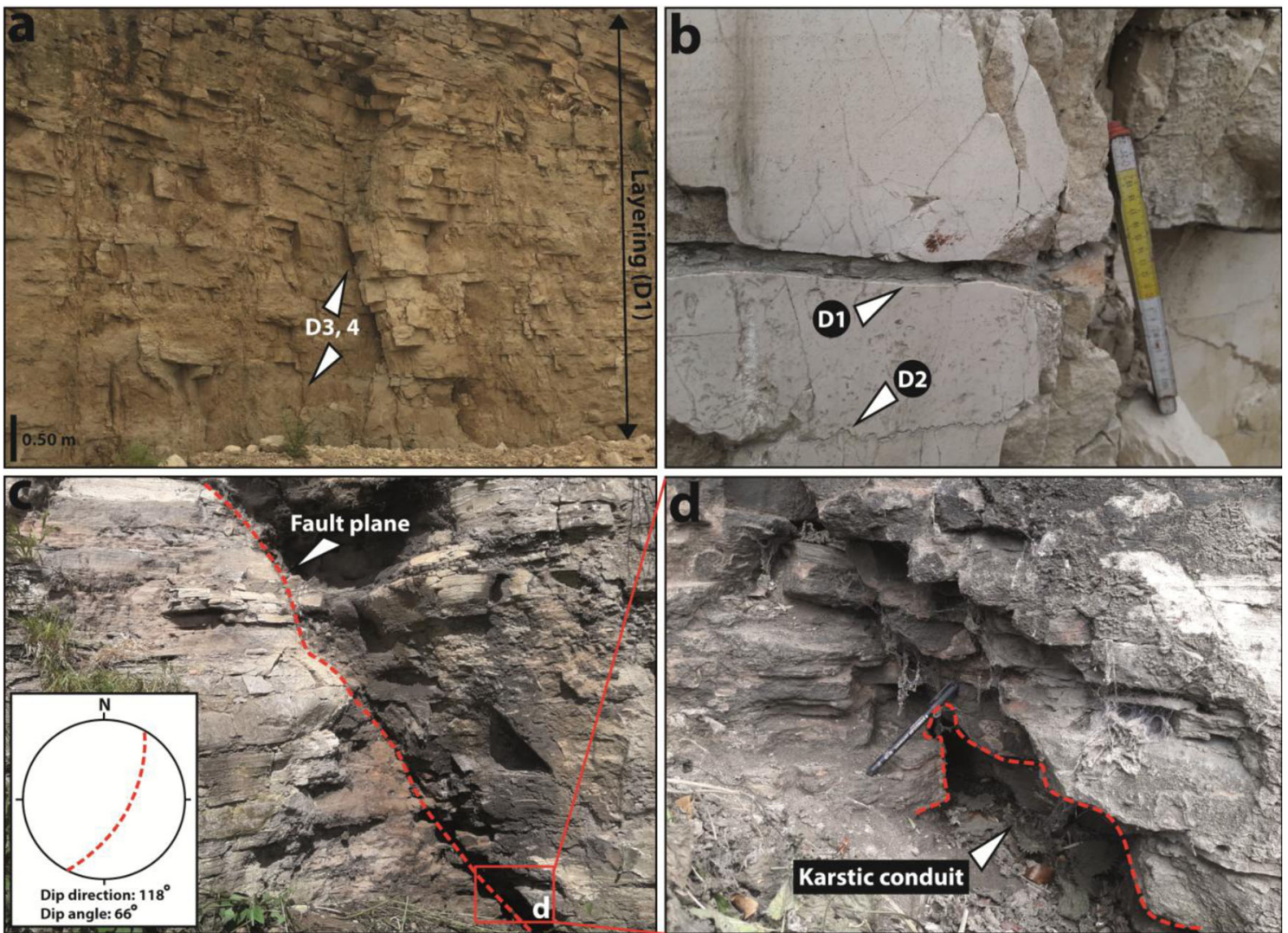

Fig. 3 Outcropping Magnesian Limestone Group (see Fig. 1b for the location of quarries). a Cadeby Formation at Jackdaw Crag Quarry. b Detail of bedding fracture (D1) and detail of stylolite (D2) in the

Cadeby Formation at Highmoor Quarry. c Extensional fault in the Brotherton Formation outcropping in 'the Dales Quarry'. d Karstic conduit in the fault zone at 'the Dales Quarry', Brotherton Formation

The infilling of geological discontinuities $(n=401$; D1D6) has also been recorded in the scanline surveys. Such

discontinuities have been divided into clay (35\%), calcitedolomite (15\%), and clean (49\%) discontinuities.

Table 1 Details of scanline data acquired in the Magnesian Limestone Group in the Leeds-York area (see Fig. 1b for the location). The initial lower case $\mathrm{h}$ and $\mathrm{v}$ represent horizontal and vertical scanlines, and numbers 1 and 2 indicate horizontal surveys in orthogonal directions uppercase letter of the scanline code represents the quarry site initial,

\begin{tabular}{|c|c|c|c|c|c|c|}
\hline Field site & Population $(n)$ & Scanline code & Face orientation & Scanline length (m) & Average spacing (m) & Standard deviation, $\sigma(\mathrm{m})$ \\
\hline Jackdaw Crag Quarry & 31 & $\mathrm{~J}, \mathrm{~h}$ & $35-215^{\circ}$ & 9.0 & 0.27 & 0.08 \\
\hline \multirow[t]{3}{*}{ Highmoor Quarry } & 52 & $\mathrm{H}$ h1 & $125-305^{\circ}$ & 7.0 & 0.13 & 0.01 \\
\hline & 8 & $\mathrm{H}$ h2 & $20-200^{\circ}$ & 1.0 & 0.12 & 0.06 \\
\hline & 46 & $\mathrm{H} \mathrm{v}$ & $110-290^{\circ}$ & 4.0 & 0.09 & 0.09 \\
\hline \multirow[t]{2}{*}{ Newthorpe Quarry } & 28 & $\mathrm{Nh}$ & $120-210^{\circ}$ & 4.0 & 0.20 & 0.01 \\
\hline & 12 & $\mathrm{~N} \mathrm{v}$ & $125-215^{\circ}$ & 1.8 & 0.15 & 0.01 \\
\hline \multirow[t]{3}{*}{ Wellhouse Farm Quarry } & 12 & W h1 & $2-182^{\circ}$ & 2.0 & 0.15 & 0.06 \\
\hline & 14 & $\mathrm{~W} \mathrm{~h} 2$ & $50-230^{\circ}$ & 2.0 & 0.14 & 0.12 \\
\hline & 9 & $\mathrm{~W} v$ & $90-270^{\circ}$ & 2.5 & 0.26 & 0.22 \\
\hline \multirow[t]{3}{*}{ The Dales } & 26 & D h1 & $102-282^{\circ}$ & 1.5 & 0.05 & 0.06 \\
\hline & 12 & $\mathrm{D}$ h2 & $10-190^{\circ}$ & 1.4 & 0.09 & 0.07 \\
\hline & 24 & $\mathrm{D} v$ & $115-295^{\circ}$ & 1.3 & 0.04 & 0.03 \\
\hline \multirow[t]{3}{*}{ Byram Nurseries } & 27 & B h1 & $12-192^{\circ}$ & 4.0 & 0.15 & 0.08 \\
\hline & 80 & B h2 & $20-200^{\circ}$ & 7.0 & 0.14 & 0.08 \\
\hline & 20 & B v & $20-120^{\circ}$ & 1.0 & 0.05 & 0.04 \\
\hline
\end{tabular}



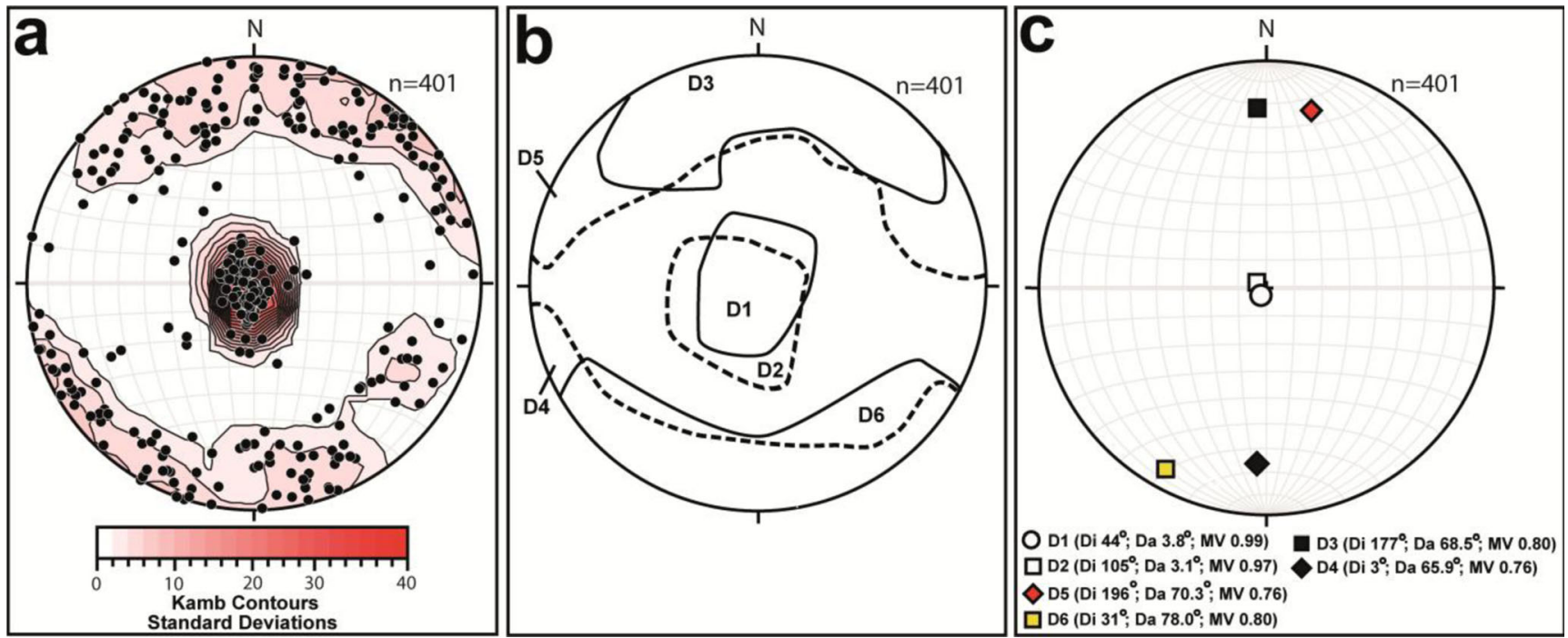

Fig. 4 Stereoplots of pole to planes (upper hemisphere, equal area) from 14 scanline surveys carried out in 6 different quarries in the Leeds-York area. a Contours. b Grouping of discontinuities (D1-D6). c Mean vectors of discontinuities (D1-D6)

\section{Physiochemical properties of groundwater}

Physiochemical parameters of groundwater were determined on six occasions during the hydraulic year (JanOct, see hydraulic head variation vs. sampling times in Fig. S2) in $\mathrm{BH} 1, \mathrm{BH} 2$, and $\mathrm{BH} 3$ boreholes. Results from this monitoring are summarized in Figs. 5 and 6 and Table 3. The Piper diagram (Fig. 5) shows a $\mathrm{Ca}^{2+}-\mathrm{Mg}^{2+}$ bicarbonate-type composition. The order of abundance is $\mathrm{Ca}^{2+}>\mathrm{Mg}^{2+}>\mathrm{Na}^{+}>\mathrm{Al}^{3+}>\mathrm{Mn}^{2+}>\mathrm{Fe}^{2+}$ and $\mathrm{HCO}^{3-}>$ $\mathrm{SO}^{2-}>\mathrm{Cl}^{-}>\mathrm{NO}_{3}{ }^{-}$for cations and anions, respectively. Nitrate concentrations are always above the WHO drinking water limit of $50 \mathrm{mg} / \mathrm{L}$ in $\mathrm{BH} 2(55-118 \mathrm{mg} / \mathrm{L})$ and $\mathrm{BH} 3(60-125 \mathrm{mg} / \mathrm{L})$; in $\mathrm{BH} 1$, they ranged from 40 to $65 \mathrm{mg} / \mathrm{L}$.

The mean $\mathrm{pH}$ of groundwater was 7.30 (range 7.01-7.60); mean fluid temperature was $10.0^{\circ}$ (range $9.5-11.0^{\circ}$ ). Electrical conductivity ranged from 775 to $1086 \mu \mathrm{S} / \mathrm{cm}$ (Fig. 6). DOC ranges from 1.0 up to $13.8 \mathrm{mg} / \mathrm{L}$ (Fig. 6) and shows a wider seasonal variation than the other parameters with higher concentrations observed in the spring-summer period (late April-June).
Saturation indexes (SI) for calcite, dolomite, and aragonite and $\mathrm{pCO}_{2}$ computed from concentrations of $\mathrm{Ca}^{2+}$ and $\mathrm{Mg}^{2+}$, alkalinity, $\mathrm{pH}$, and fluid temperature (Table 3 ) ranged from 0.001 up to 0.026 . These values are higher than the atmospheric pCO2 of 0.00035 as is common for soil and groundwater (Talling 2006). Saturation indexes (SI) of calcite, aragonite, and dolomite lie in the range -0.5 to 0.5 (Table 3 ), which indicates saturation for these three carbonate mineral species (Bicalho et al. 2012).

\section{Groundwater flow and transport model}

The revised conceptual model of the Cadeby Formation is shown in Fig. 7 (for the upper $\sim 15 \mathrm{~m}$ below the water table which is significantly permeable). Extensional faults are characterized by partially closed fractures $(a<0.001 \mathrm{~m})$ and relatively large ( $a=0.1-0.60 \mathrm{~m}$ ) pipes (conduits), which in some places are in alignment with springs and streams (Figs. 7 and 8a). Particle tracking analysis was realized from the new groundwater flow model.

Table 2 Statistics of persistence and mechanical aperture from the scanline surveys from rock faces

\begin{tabular}{|c|c|c|c|c|c|c|c|c|}
\hline \multirow[t]{2}{*}{ Type of discontinuity } & \multirow[t]{2}{*}{ Code } & \multirow[t]{2}{*}{ Population $(n)$} & \multicolumn{3}{|c|}{ Persistence (m) } & \multicolumn{3}{|c|}{ Mechanical aperture (mm) } \\
\hline & & & Range & Arithmetic mean & $\begin{array}{l}\text { Standard deviation, } \\
\sigma(\mathrm{m})\end{array}$ & Range & Arithmetic mean & $\begin{array}{l}\text { Standard deviation, } \\
\sigma(\mathrm{mm})\end{array}$ \\
\hline Joints & D1, D2 & 157 & $0.07-3.90$ & 0.66 & 0.08 & $0-2.2$ & 0.6 & 0.6 \\
\hline Fault-related fractures & D3, D4 & 105 & $0.01-3.60$ & 0.62 & 0.10 & $0-60.0$ & 1.7 & 6.1 \\
\hline Bedding planes & D5, D6 & 114 & $0.60-60$ & 3.42 & 0.20 & $0-2.5$ & 0.7 & 0.6 \\
\hline Stylolites & D7, D8 & 26 & $0.06-6.00$ & 0.62 & 0.10 & $0-0.9$ & 0.3 & 0.3 \\
\hline
\end{tabular}


Fig. 5 Piper diagram for water samples from $\mathrm{BH} 1, \mathrm{BH} 2$, and $\mathrm{BH} 3$

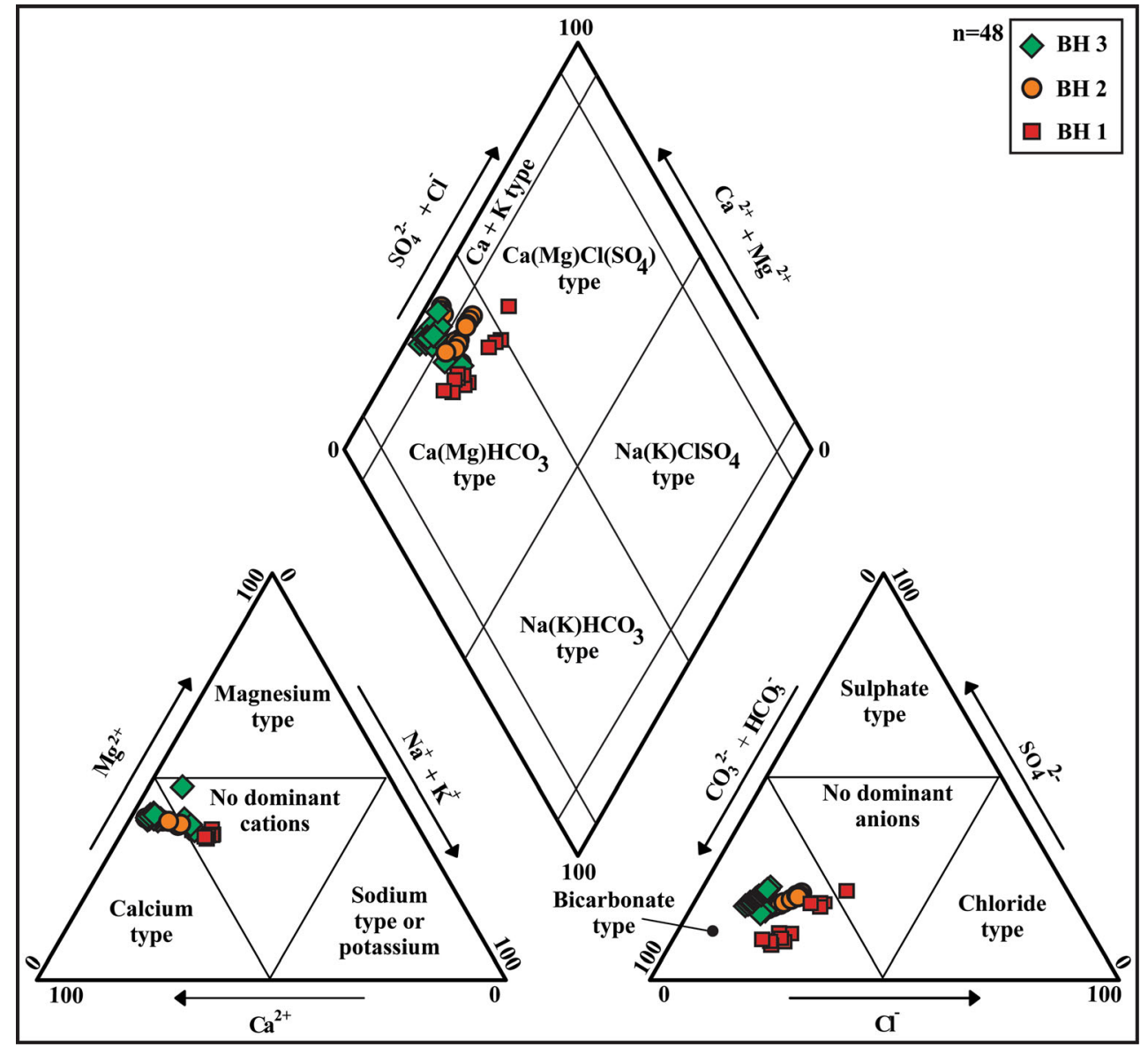

\section{Pre-existing groundwater flow model (Environment Agency 2009)}

The Environment Agency (2009) groundwater flow model covers an area approximately $16 \mathrm{~km} \mathrm{E-W}$ by $13 \mathrm{~km} \mathrm{~N}-\mathrm{S}$; Fig. $1 \mathrm{~b}$ shows the model boundaries, also shown in Fig. 8ac. The grid consists of 185 rows and 205 columns; the finitedifference cell dimension is $100 \times 100 \mathrm{~m}$. The $3 \mathrm{D}$ grid is characterized by three layers which represented the Cadeby (lowest, layer 1), Edlington (layer 2), and Brotherton (uppermost, layer 3) formations of the UK Magnesian Limestone, respectively. Note that the water table decreases towards the east. Thus, some parts of the Brotherton Formation (layer 3) are unsaturated in the eastern area of the model. The Edlington Formation (evaporitic marl) is an aquitard represented with hydraulic conductivity $\sim 10^{3}$ times lower than the carbonate units of the Cadeby and Brotherton formations. Vertical flow anisotropies $\left(K_{x} / K_{z}=100\right.$ for layer 1 , see Table 4$)$ are set to typical values of fractured carbonate aquifers with flow dominated by subhorizontal bedding plane fractures (Boulton 1970; Odling et al. 2013). Layer thicknesses and position of faults (Fig. 8a) are based on the British Geological Survey 3D geological model (Cooper and Lawley 2007) which is built on 5 seismic lines and 300 and 55 boreholes which penetrate the
Quaternary sequence and UK Magnesian Limestone, respectively (Cooper and Lawley 2007; EA 2009). Mapped fault traces are represented as very high hydraulic conductivity cells within the Cadeby Formation as shown in Table 4.

\section{New groundwater flow model}

The new 3D steady-state groundwater flow model has been re-calibrated by auto-sensitivity analysis of hydraulic conductivity of faults and layers; i.e., the model implementation is exclusively aimed at optimizing groundwater flow with respect to specific geological structures (bedding planes, nonstratabound fractures, and faults).

In the new model (see Fig. 8a-c), the greatest input to groundwater is rainfall recharge (average $134 \mathrm{~mm} /$ year resulting in $\sim 78 \%$ of inflow). The next greatest input (representing 13\%) is flow from the underlying Carboniferous strata. Other smaller inputs (9\%) result from leakage from losing reaches of surface water courses. The greatest output from groundwater $(50 \%)$ is the baseflow to the River Wharfe. Baseflow to the Cock and Bramham Becks makes up another $33 \%$ of the total outflows. Abstraction in the Leeds-York area (see Fig. 8a) accounts for approximately $13 \%$ of the outflows. An additional $4 \%$ is 


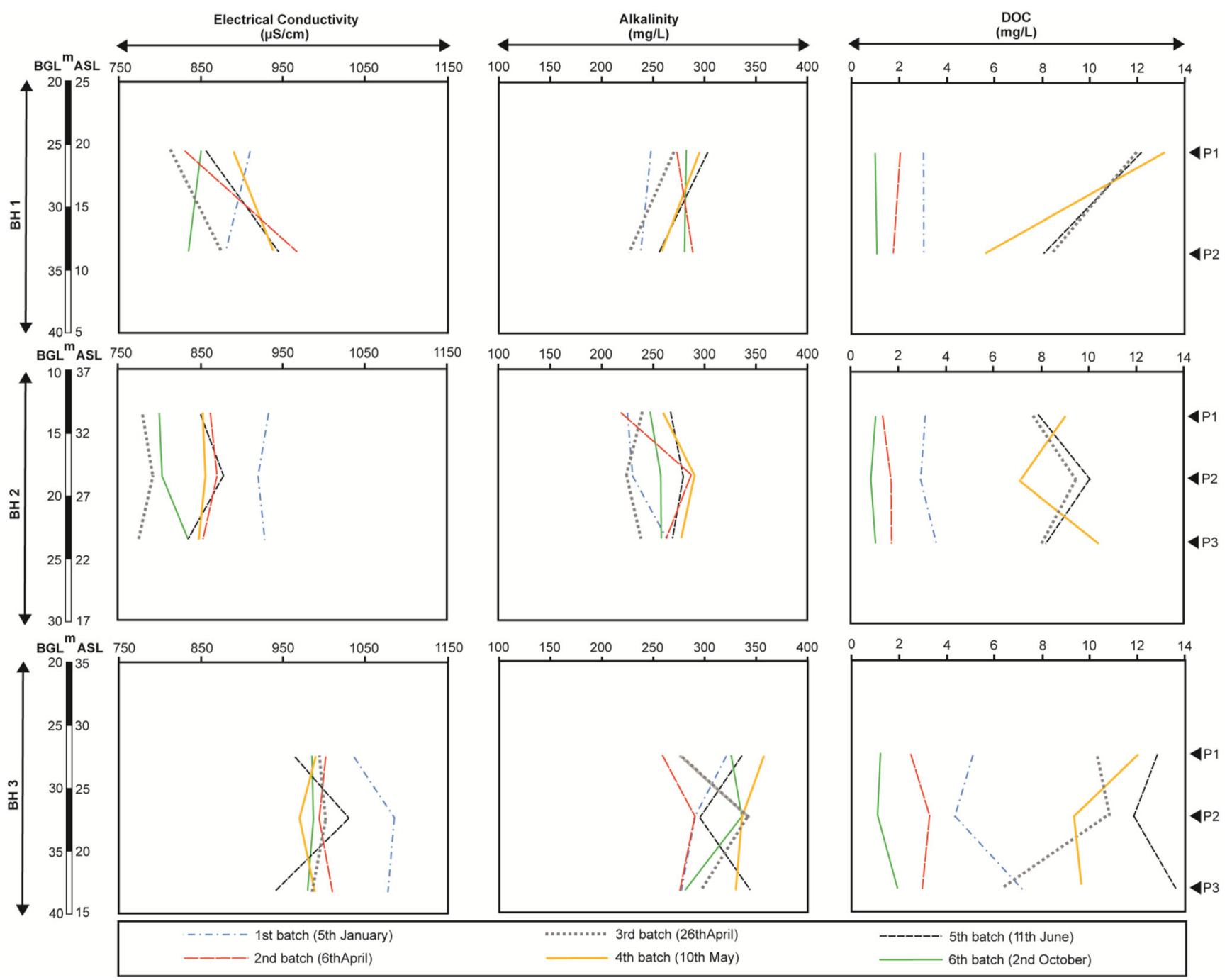

Fig. 6 Plots of electrical conductivity, alkalinity, and DOC measured on six dates during 2018 versus depth of piezometer interval in BH1, BH2, and $\mathrm{BH} 3$ boreholes

represented by flow from the aquifer across the southern general head boundary.

Previous research at the University of Leeds farm (Figs. $1 \mathrm{~b}$ and $2 \mathrm{a}$ ) shows a high hydraulic conductivity ( $K=0.83-2.85 \mathrm{~m} /$ day) in the first $\sim 15 \mathrm{~m}$ immediately below the water table in the Cadeby Formation (Medici et al. 2019a), with much lower values below. As a consequence, the effective thickness of the aquifer was reduced to $\sim 15 \mathrm{~m}$ by truncation of the bottom of the Cadeby Formation (layer 1), as indicated in the conceptual model (Fig. 7).

Vertical layer anisotropy $\left(K_{x} / K_{z}=100\right.$ for layer 1$)$ values were unchanged from the previous model as hydrogeophysical characterization confirmed the importance of bedding fracture flow. The model hydraulic conductivity (see Table 4) has also been modified in correspondence of mapped extensional fault traces to values of 2.5 times higher than the background in zones $100 \mathrm{~m}$ wide, to account for high fracturing density (Table 1). The unfeasibly high hydraulic conductivity (e.g., $500 \mathrm{~m} / \mathrm{d}$, Table 4 ) values used in the previous model in correspondence with fault zones are represented instead using the Conduit Flow Process Mode 1 elements (pipes). This accounts for laminar and turbulent flow of relatively large $(0.1-0.6 \mathrm{~m})$ conduits observed in outcrops (e.g., Fig. 3d).

The new groundwater model (Fig. 8a-c) was calibrated by automatic sensitivity analysis based on hydraulic conductivity in un-faulted areas and pipe diameter in fault zones. Hydraulic conductivity of fault zone cells was fixed to $5 \mathrm{~m} /$ day. Conductance of pipe elements ranges from 15 to $38 \mathrm{~m}^{2} /$ day as a function of the hydraulic gradient (which varies from 0.005 to 0.0024 across the model area, see Fig. 8c). These values of pipe conductance come from the pipe diameter of $0.20 \mathrm{~m}$, determined during calibration. This process produced similar calibration statistics of the Environment Agency (2009) model, with residual mean and absolute residual mean 


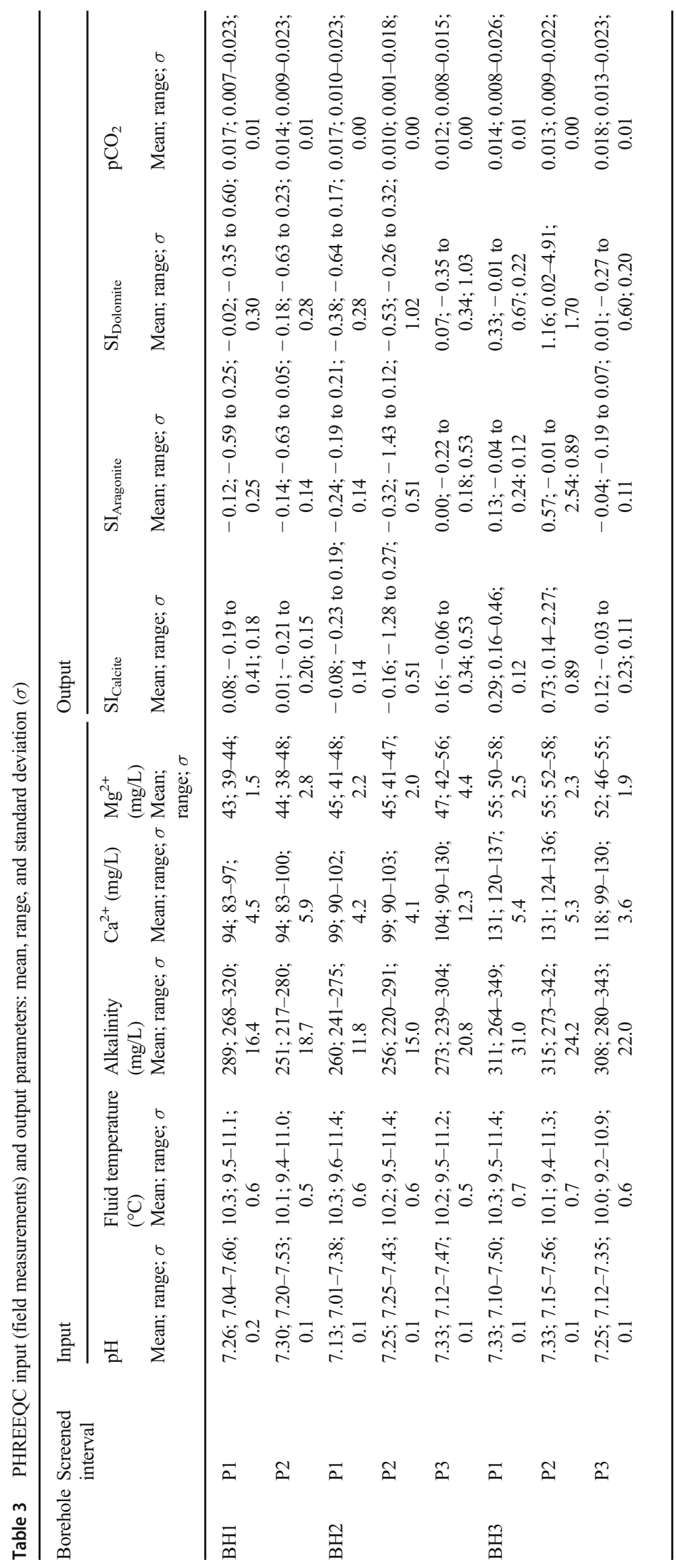


Fig. 7 Conceptual model of groundwater flow in the fractured and faulted carbonate aquifer of the Magnesian Limestone Group

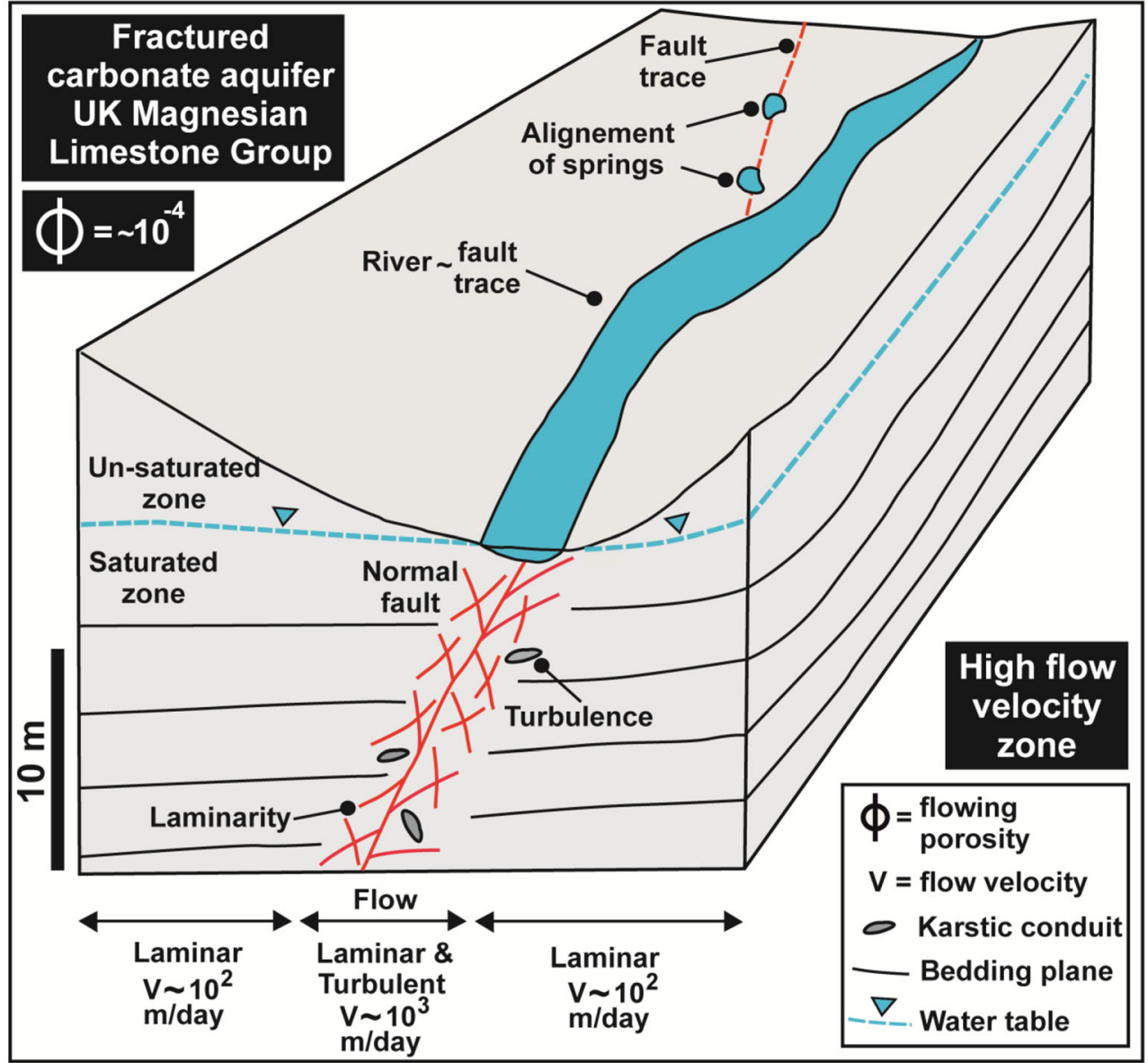

of -1.43 and $3.90 \mathrm{~m}$, respectively. Including a horizontal anisotropy $\left(K_{x} / K_{y}=1.2\right)$ to represent the preferential E-W joint orientation (see Figs. 4 and S1) slightly improved model calibration (Table 4). A plot of observed vs. simulated hydraulic head for 47 observation wells is shown in Figure S2. The maximum residual of $6.5 \mathrm{~m}$ is $<10 \%$ of the hydraulic head range. Residual mean and absolute residual mean are -1.33 and $3.36 \mathrm{~m}$, respectively (Fig. S2).

A flow velocity field around a normal fault zone is shown in Fig. 9a-c. This is a detail of the velocity field (obtained with flowing porosity of $2.8 \times 10^{-4}$ ) in the north western sector of the 3D steady-state flow (see Fig. 8a for position). Groundwater flow velocities ranged from 500 up to $9000 \mathrm{~m} /$ day (Fig. 9b, c) in correspondence of the fault zone. Such high values are spatially confined to the region around the conduit flow path (CFP-1) pipe element accounting for the $25 \%$ of the cells in the selected model area (Fig. 9c). The highest flow velocities $(\sim 1000-9000 \mathrm{~m} /$ day) concern cells directly in correspondence of the CFPM-1 pipes with vectors subparallel to these elements (see Fig. 9a, b). However, flow velocities rapidly decrease away from the faults, reaching values of $200 \mathrm{~m} /$ day at $\sim 300 \mathrm{~m}$ distance. Similar values $(150-400 \mathrm{~m} /$ day) dominate un-faulted areas accounting for the $75 \%$ of the cells (Fig. 9c). Note that all groundwater flow velocities in this model are lower by a factor of $\sim 10^{2}$ by alternatively using the previously published value of flowing porosity $\left(5.0 \times 10^{-2}\right.$; Neymeyer et al. 2007), used for particle tracking in this carbonate aquifer of the Permian age.

\section{Particle tracking analysis}

Values of effective flow porosity represent the key parameter that controls backward particle tracking as shown in Fig. 10. The upper panels show 50-day traces and the lower panels 400-day traces. The scenario shown on the left side of this figure is based on the lower value of effective flow porosity $\left(2.8 \times 10^{-4}\right)$ of the non-faulted areas derived from hydraulic testing in the central part of the model area (Medici et al. 2019a). Hydrogeophysics has been specifically applied on the Cadeby Formation which is the unique layer involved in particle tracking. Hence, this scenario is more likely to be correct. In that case, karstified faults strongly influence particle tracks. Indeed, particles can reach faults and are then rapidly transported along segments of such tectonic structures (see Fig. 10, left side). Note that the low values of effective flowing porosity show evidence of hydraulic connection between abstraction wells and streams via faults (Fig. 10). Particles are transported at high velocity $\left(\sim 10^{3} \mathrm{~m} /\right.$ day $)$ until 
Fig. 8 3D steady-state groundwater flow model of the

Magnesian Limestone in the Leeds-York area. a Model area showing rivers, location of springs, abstractions wells, and mapped fault traces. b Cadeby Formation, layer 1 (the main flowing layer), red lines are fault cells, green are stream cells, and yellow are drain cells. c

Calibrated model hydraulic heads (ASL) within the Cadeby

Formation, lowermost layer (layer 1)
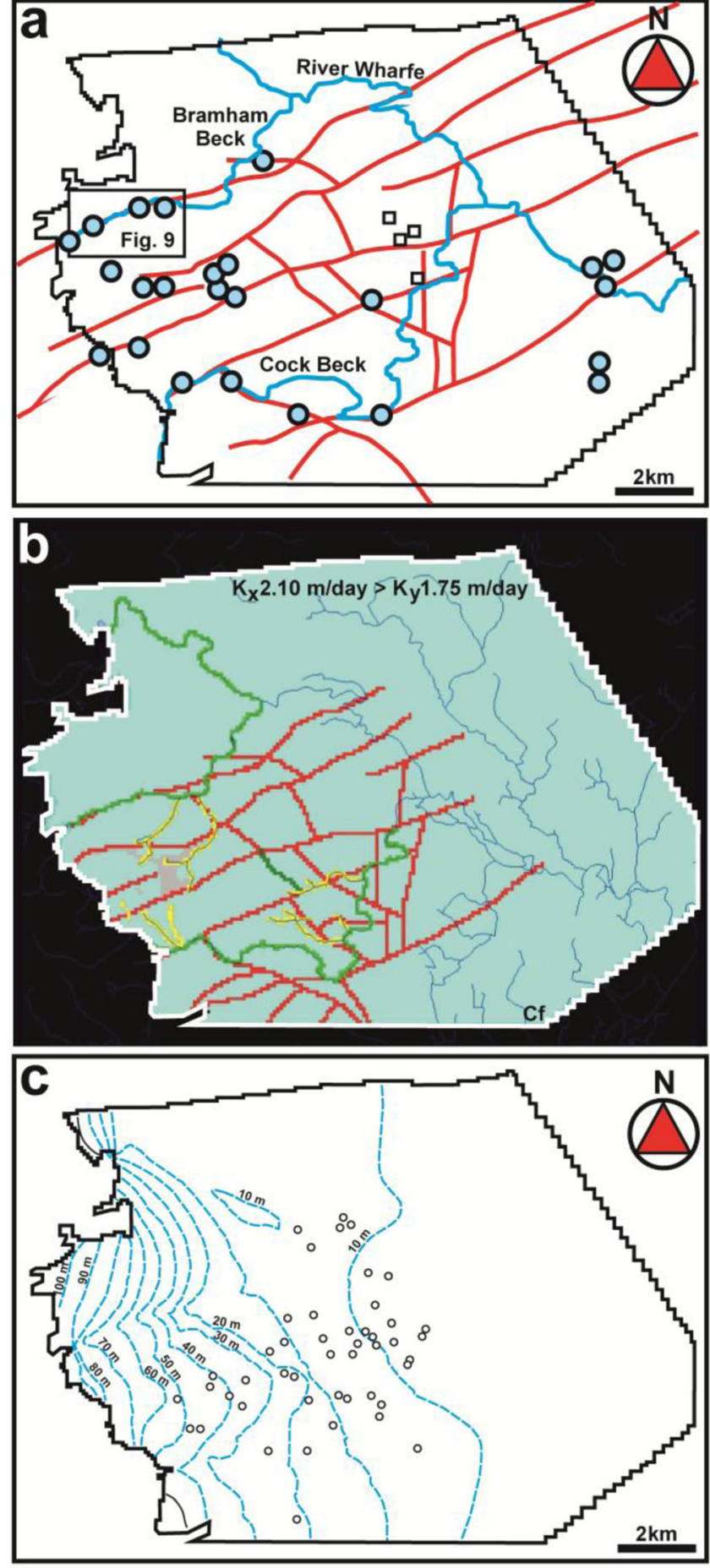

Cf

Cadeby Formation (Layer 1)

Springs

$K=$ Hydraulic conductivity

$\mathrm{x}=\mathrm{E}-\mathrm{W}$ oriented axis

$y=N-S$ oriented axis

$\square$ Abstraction wells

o Observation wells
Faults

( $5 \mathrm{~m} / \mathrm{day}$ )

Principal rivers and streams

Groundwater contours mASL) 
the flow vectors bring them to an area not affected by CFPM-1 pipe elements.

In contrast, using the higher effective porosity $\left(5.0 \times 10^{-2}\right)$ from the Neymeyer et al. (2007) study (Fig. 10, right side of panels) does not produce traces long enough to reach the fault zones in 50 days, although some are reached in 400 days. This highlights that identification of the flowing porosity of the unfaulted areas is critical for correctly predicting aquifer vulnerability.

Notably, MODPATH was initially run using the very high values of fault zone hydraulic conductivity in the pre-existing model ( $K=10-1000$ m/day; Environment Agency 2009) rather than the CFPM-1 elements. This approach equally produces particle tracks subparallel to faults which spatially localize particles. However, the latter flow velocity field around and within fault zones is incorrect because flow velocities are too high for Darcian flow.

\section{Discussion}

\section{Groundwater chemistry and karstification}

Hydrochemistry data show a $\mathrm{Ca}^{2+}-\mathrm{Mg}^{2+}$ bicarbonate-type composition for the groundwater in the Cadeby Formation of the Magnesian Limestone Group. This is the typical composition of groundwater in dolostones and dolomitic limestone aquifers (Falcone et al. 2008; Mudarra and Andreo 2011, Xanke et al. 2015; Palmucci et al. 2016; Zhang et al. 2016). Saturation indexes computed for calcite, aragonite, and dolomite (Table 3 ) indicate that the groundwater is saturated with respect to these three mineral species. Despite this, the UK Magnesian Limestone shows karstic fracture aperture enhancement in the top $\sim 15 \mathrm{~m}$ below the water table, as well as karst conduit features as a result of faults which are represented in the new groundwater flow model. Such karstic development is most likely driven by in situ bacterial consumption of DOC present in the groundwater, derived from the soil zone, as well as external input of $\mathrm{CO}_{2}$ via the gas phase from the soil

Table 4 Hydraulic conductivity values of the Cadeby Formation (layer 3 ), a unique layer involved in particle tracking analysis, including median from slug tests and pumping tests and calibrated model values for previous and new steady-state models

\begin{tabular}{|c|c|c|c|c|}
\hline $\begin{array}{l}\text { Model } \\
\text { area }\end{array}$ & $\begin{array}{l}\text { Slug tests, } \\
\text { Medici et al. } \\
2019(K) \\
(\mathrm{m} / \text { day) }\end{array}$ & $\begin{array}{l}\text { Pumping tests, } \\
\text { Allen et al. } \\
1997(\mathrm{~K}) \\
\text { (m/day) }\end{array}$ & $\begin{array}{l}\text { Model, EA } \\
2009\left(K_{x},\right. \\
\left.K_{y}, K_{z}\right) \\
(\mathrm{m} / \text { day })\end{array}$ & $\begin{array}{l}\text { New model, } \\
\text { this work }\left(K_{x},\right. \\
\left.K_{y}, K_{z}\right) \\
\text { (m/day) }\end{array}$ \\
\hline Un-faulted & 1.0 & 1.3 & $\begin{array}{c}1.75,1.75 \\
0.0075\end{array}$ & $\begin{array}{c}1.75,2.1 \\
0.021\end{array}$ \\
\hline Faulted & N/A & 200 & $\begin{array}{c}500,500 \\
500\end{array}$ & $5,5,5$ \\
\hline
\end{tabular}

zone. Holden et al. (2019) observed that arable practices, such as ploughing, increased decomposition rates of soil organic matter that leads to an increase in the release of carbon dioxide. Our hydrochemical analyses (see Table 3 ) confirm this scenario. The fact that $\mathrm{pCO}_{2}$ is higher in the groundwater of the Cadeby Formation with respect to the atmosphere leads to the $\mathrm{pH}$ of water being lower than the value of 8.3 in equilibrium with atmospheric $\mathrm{CO}_{2}$ (Table 3 ). These conditions will lead to continued dissolution of the limestone/dolomite, creating karst porosity along fractures and conduits.

Dolomitic rock observed in the field is weaker in correspondence of faults as a consequence of cataclasis and higher fracturing density (Table 1). This favours localization of streams in correspondence of normal faults as depicted and modelized in Figs. 7 and 10, respectively. As a consequence, more intense groundwater dissolution occurs due to allochthonous groundwater from streams which are characterized by much higher $\mathrm{pCO}_{2}$ (Banks et al. 1995; Worthington and Ford 2009; Gulley et al. 2015). Cavities up to 0.60-m diameter found at the disused quarries investigated in correspondence of faults (Figs. 1b and 3c, d) may result from such dissolution. Breccia pipes previously observed in quarries in the LeedsYork area and dolines mapped in correspondence of fault traces in the Cadeby and Brotherton formations $\sim 40 \mathrm{~km}$ south with respect to the model area are further indicators of macrokarst development (Murphy 2000; Cooper and Lawley 2007; Farrant and Cooper 2008). Here, we have attempted to accurately model groundwater flow in a highly fractured and karstified area of carbonate aquifers affected by such extensional faults.

\section{Effective porosity and particle tracking analysis}

This research has shown that effective flowing porosity is a key parameter for particle tracking analysis. However, a wide range of effective flowing porosity values have been reported in the literature even for the same aquifer (see Fig. 10). The low average value $\left(2.8 \times 10^{-4}\right)$ that was determined by Medici et al. (2019a) for the UK Magnesian Limestone followed rigorous approaches that were recently used for fractured aquifers in Northern America (Quinn et al. 2011; Maldaner et al. 2018; Ren et al. 2018). All these studies couple acoustic televiewer logs with fluid or dilution tests to individuate flowing fractures. Then, the cubic law is applied to calculate the average hydraulic aperture using slug or pumping tests. The effective flowing porosity $\left(2.8 \times 10^{-4}\right)$ value which is illustrated in the conceptual model in Fig. 7 closely matches that one found in the Palaeozoic granites of Wyoming $\left(3.9 \times 10^{-4}\right.$, Ren et al. 2018) and the Permian dolostone of Ontario $\left(2.6 \times 10^{-4}\right.$, Quinn et al. 2011; Maldaner et al. 2018). Note that the use of the cubic law to extrapolate hydraulic apertures $(0.10$ $0.54 \mathrm{~mm}$ ) in the Cadeby Formation is also broadly supported by outcrop analyses reported here; i.e., $80 \%$ of discontinuities 
Fig. 9 3D steady-state flow velocity field and NW model subarea (see Fig. 8a). a Vector flow direction and modelled fault, river, and CFPM-1 pipe element. b Map of flow velocity. c

Frequency histogram of flow velocity for the subarea shown

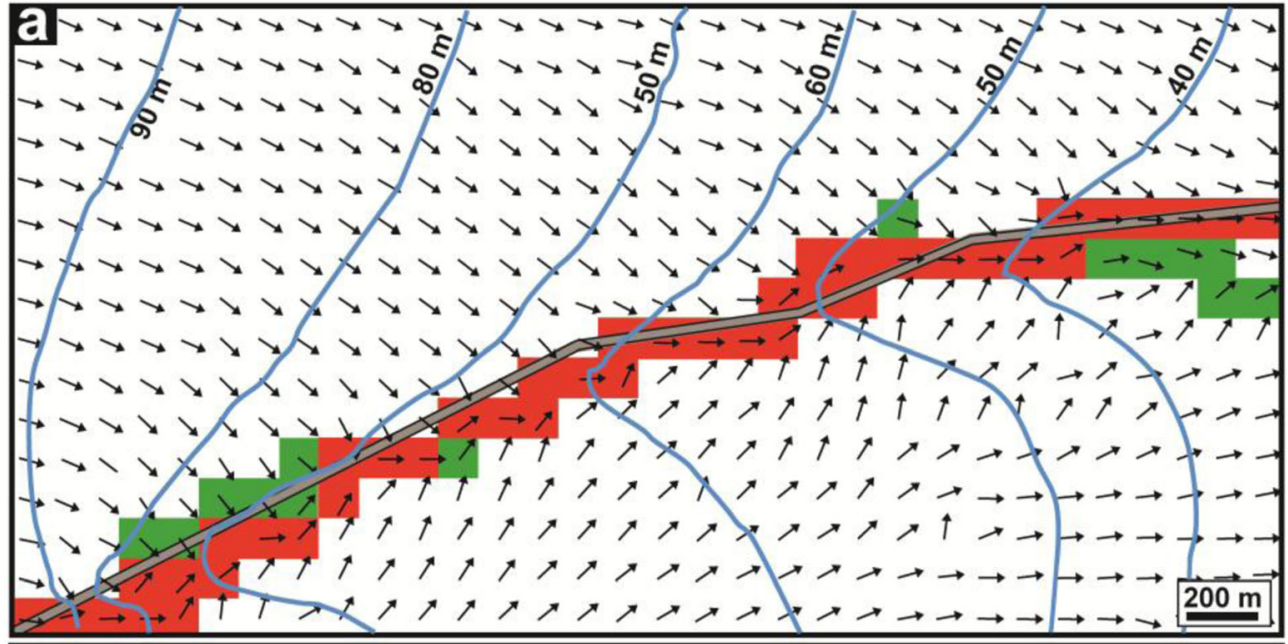

\begin{tabular}{l|l|l|l|l|}
$\begin{array}{l}\text { Groundwater } \\
\text { contours mASL }\end{array}$ & Fault \\
$\begin{array}{l}\text { Flow velocity } \\
\text { - vector direction }\end{array}$ & River
\end{tabular} \mid $\begin{aligned} & \text { Cell } \\
& \begin{array}{l}\text { Conduit flow } \\
\text { path element } \\
\text { (CFPM-1) }\end{array}\end{aligned}$
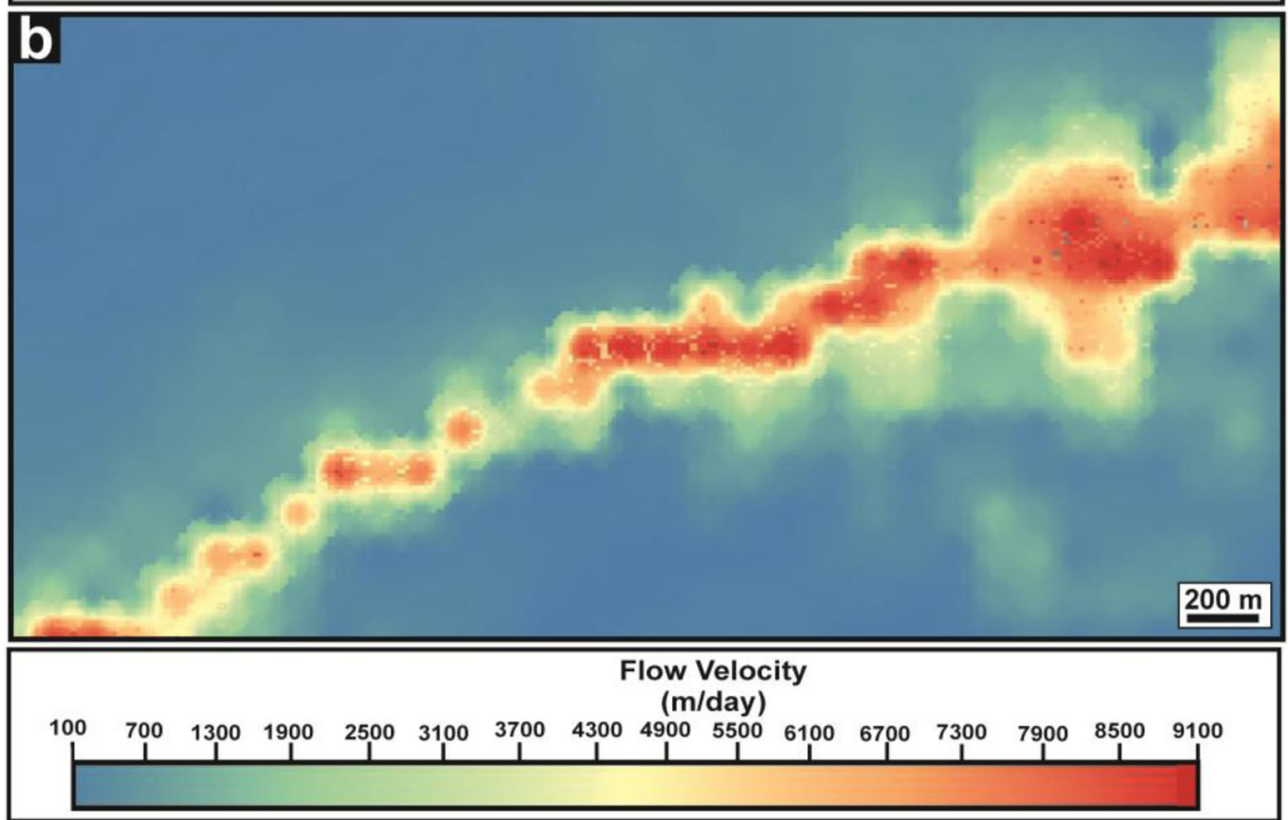

C

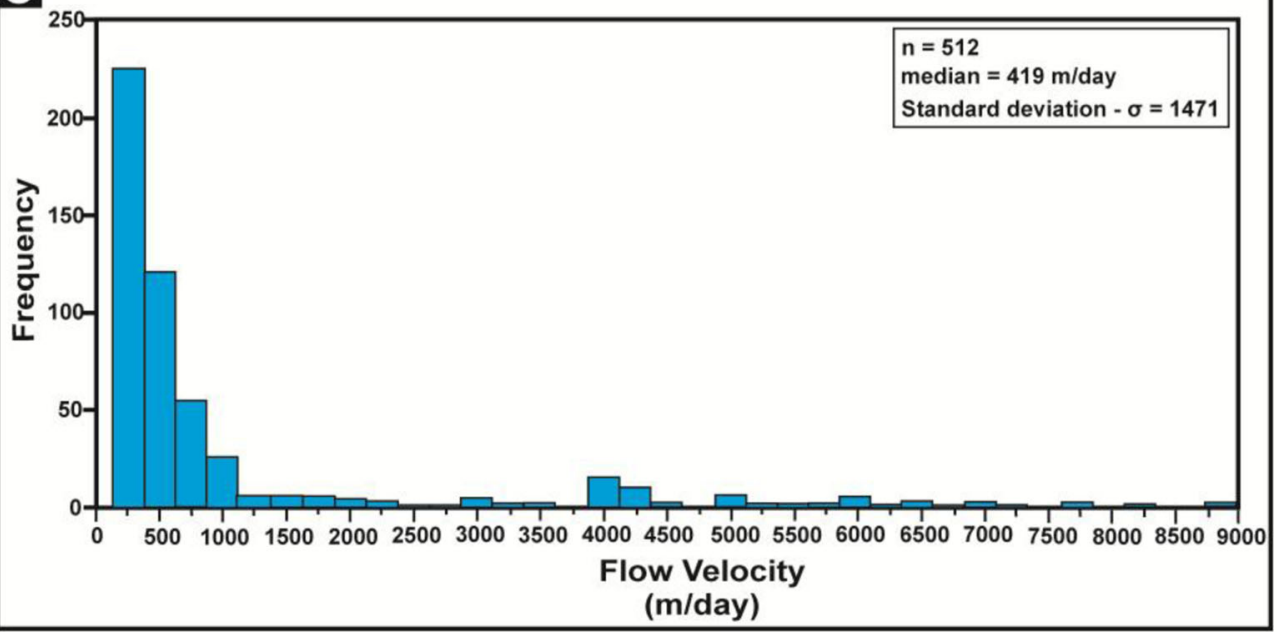


recorded in non-faulted areas have mechanical apertures < $1 \mathrm{~mm}$, closely matching hydraulic apertures.

This contrasts with the flowing porosities $\left(\sim 10^{-1}-10^{-3}\right)$ used for MODPATH particle tracking previously published for fracture-flow carbonate aquifers (e.g., Rayne et al. 2001; Neymeyer et al. 2007; Bredehoeft and King 2009; Yager et al. 2013; Zuffianò et al. 2016; Gárfias et al. 2018). Indeed, $5.0 \times$ $10^{-2}$ has been used for the Cambrian-Ordovician limestone of Nevada (Bredehoeft and King 2009), the Permian dolostone of NE England (Neymeyer et al. 2007), the Jurassic limestone of Southern Italy (Zuffianò et al. 2016), and the Cretaceous dolostone of southern Spain (Gárfias et al. 2018). However, this relatively high value $\left(5.0 \times 10^{-2}\right)$ of effective porosity appears unsupported by hydrogeophysical borehole testing. A similar effective porosity $\left(1.0 \times 10^{-2}\right)$ was used for particle tracking analysis in the Palaeozoic fractured carbonates of West Virginia (Yager et al. 2013). Use of these higher values appears to lead to large underestimation of contaminant transport rates in such porous geological media. As a consequence, we believe that much more experimental efforts are needed to determine more accurate effective flow porosity values, which have been typically either subject to uncertainty or overestimated by groundwater modellers.

\section{Structural geology and particle tracking analysis}

Backward particle tracking analysis (see Fig. 10) in the UK Magnesian Limestone of NE Yorkshire has highlighted the important role that extensional faults play as preferential pathways for contaminant transport. This arises from their much higher $\left(\sim 10^{3} \mathrm{~m} /\right.$ day $)$ groundwater flow velocity due to the higher fracturing density coupled with karstic macroporosity structures (see Fig. 7). From a conceptual point of view, normal faults must be modelled accounting for their

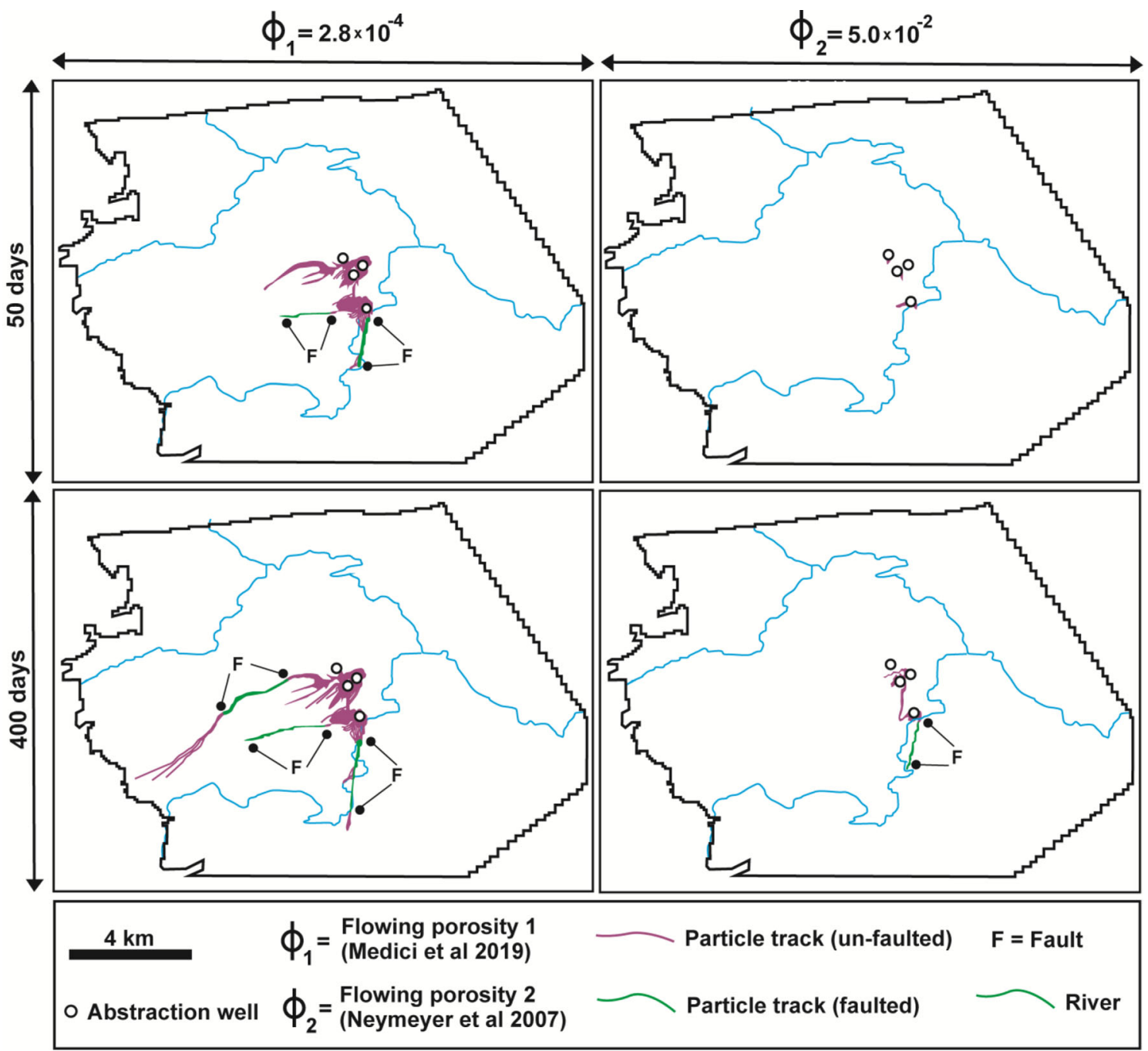

Fig. 10 Backward particle tracking analysis from abstraction wells in the Cadeby Formation (layer 1). Left panels use the lower flowing porosity of the equivalent porous medium representing flow porosity in narrow fractures of $2.8 \times 10^{-4}$ from hydrogeophysical characterization; righthand panels use a more conventional higher value of $5.0 \times 10^{-2}$ 
high hydraulic conductivity away from such conduits due to the presence of high-density less intensively karstified fractures. Indeed, a hydraulic conductivity higher than that of the un-faulted Cadeby Formation has been used in the groundwater flow model (Table 4). Discontinuity surveys performed in the vicinity of a normal fault in the UK Magnesian Limestone Group (see Fig. 3c) show that $58 \%$ of fractures are characterized by mechanical aperture $<1 \mathrm{~mm}$. These values which are likely to be enhanced by unloading at quarry faces still suggest a laminar flow regime. Borehole testing reported by Medici et al. (2019a) indicates laminarity at hydraulic apertures from 0.10 up to $0.54 \mathrm{~mm}$.

Despite this, a major part of fault permeability is likely to be related to a network of pipes. Cavities with rounded and angular shapes (see Fig. 3d) were recognized in outcrops in the UK Magnesian Limestone Group. Such structures typically represent fault jogs enlarged by groundwater alteration (Billi et al. 2007; Woodcock and Mort 2008). Cavities with 0.1- to 0.60-m diameter have been recognized in fault zones in this Permian aquifer. A 0.20-m diameter has been found to model flow in the CFPM-1 pipe flow framework following model calibration. Such diameters suggest turbulence based on Eqs. (1) and (2) given the hydraulic gradients present. A similar hydrostructural pattern with cavities (Fig. 3d) and springs (Figs. 7 and 8a) in correspondence of faults has been recognized in many geological realms of the word such as the Carboniferous limestones of Western Ireland (Gillespie et al. 2001; Perriquet et al. 2014), in the Triassic dolomitic limestones in Austria (Bauer et al. 2016), and in the Jurassic limestones of Central and Southern Italy (Galdenzi and Menichetti 1995; Billi et al. 2007; Petrella et al. 2007; Barberio et al. 2017). Notably, the coupling of low values of effective flowing porosity and rigorous modelling of fault permeability (see the left side of Fig. 10) show a hydraulic scenario which links abstraction wells to losing streams via faults. As a consequence, the vulnerability of heavy tectonised carbonate aquifers to contamination is very high. For example, pathogens transported by rivers are easily intercepted by abstraction wells by rapid transport through bedding plane fractures, subvertical joints, and fault-related fractures.

\section{Conclusion}

We use the example of the Permian Magnesian Limestone aquifer in the Yorkshire area (NE England, UK) to identify the drivers of karstification in the aquifer and demonstrate the importance of both rigorous determination of the flowing fracture porosity and representation of turbulent flow in karst conduits when simulating contaminant transport in fractured limestones. In this paper, we modified a previous steady-state flow model of this carbonate aquifer using data from both hydrogeophysical borehole testing and outcrop characterization and used more rigorous approaches to model groundwater flow in and around karstic cavities. The field, experimental, and modelling results of our research can be summarized in three key points:

1. The Permian Magnesian Limestone represents an example of both fractured and karstified carbonate aquifer types. Indeed, hydrochemistry analyses indicate a $\mathrm{Ca}^{2+}-\mathrm{Mg}^{2+} \mathrm{bi}-$ carbonate composition for groundwater. Saturation indexes of calcite, aragonite, and dolomite indicate saturation. Relatively high levels of dissolved organic carbon (DOC) derived from soil biomass were detected in groundwater; we hypothesise that decomposition of such DOC within groundwater produces dissolved $\mathrm{CO}_{2}$ which is responsible for karst development. This includes minor karstic enhancement of the bedding plane and joint apertures in the upper $15 \mathrm{~m}$ or so of the aquifer below the water table (mechanical aperture of $\sim 10^{-1}-1 \mathrm{~mm}$ ), which results in a laminar flow regime away from faults, and karstic cavities (diameter of $\sim 0.20 \mathrm{~m}$ ) developed along extensional faults, which likely results in a turbulent flow regime.

2. A flow model of the aquifer was developed to include a pipe network representing fault conduits which accounts for flow turbulence, coupled with an equivalent porous medium representing flow in highly conductive (but Darcian) flowing fractures. Particle tracking using the resulting flow field shows that flow in normal faults in the UK Magnesian Limestone aquifer will strongly influence well protection areas.

3. The most important parameter in particle tracking analysis remains the effective flow porosity for the equivalent porous medium (representing flow in narrow fractures). For the UK Magnesian Limestone aquifer, we recommend as most appropriate a relatively low value $\left(2.8 \times 10^{-4}\right)$ of effective flow porosity based on borehole hydrogeophysical testing. This contrasts with previous particle tracking analyses on both the UK Magnesian Limestone aquifer or many other analogous aquifers, where values of effective porosity $\sim 10^{2}$ times higher than that used this work most likely resulted in highly nonconservative estimates of groundwater vulnerability.

Following this research, we envisage further efforts on hydraulic characterization of faults and effective flow porosity for fractured media prior to the development of the conceptual and numerical models. This will lead to more reliable representation of groundwater flow and contaminant transport in carbonate aquifers in the subsurface.

Acknowledgements Harris Tarnanas and Edward Wrathmell (both Environment Agency) gave assistance with model licencing issues. Technical advice on the use of the conduit flow process was kindly provided by Thomas Reimann (Technische Universität Dresden) and Barkley Shoemaker (United States Geological Survey). 
Phillip Murphy (University of Leeds) provided information on the morphology of the caves. Recommendation of Simon Gebbett (Environment Agency) for particle tracking analysis was appreciated. MSc students Christian Walker, Claire Boddy, and Stephen Gillham are thanked for performing scanline surveys in quarries. The MSc student Zeyu Ao assisted in geochemical sampling in the field. Rachel Gaisor analysed water chemistry in the laboratory of the School of Geography, University of Leeds.

This research was also an object of interesting discussions with John Walsh (University College Dublin), Sumit Sinha (University of Leeds), and Susan Wagstaff (JBA Consulting), regarding the flow modelling of fractured limestones and dolostones. We also thank George Sorensen (University of Leeds) for his help in planning the activity of borehole instrumentation. Kirk Handley and Prodeo Agbotui from the School of Earth and Environment assisted in the fieldwork.

Funding information The authors thank NERC (CZO: Using Critical Zone Science-Peri Urban Agriculture in China Grant) and the School of Geography MSc Student Dissertation grants for funding this hydrogeological research.

Open Access This article is distributed under the terms of the Creative Commons Attribution 4.0 International License (http:// creativecommons.org/licenses/by/4.0/), which permits unrestricted use, distribution, and reproduction in any medium, provided you give appropriate credit to the original author(s) and the source, provide a link to the Creative Commons license, and indicate if changes were made.

\section{References}

Abesser C, Lewis M (2015) A semi-quantitative technique for mapping potential aquifer productivity on the national scale: example of England and Wales (UK). Hydrogeol J 23(8):1677-1694

Aldrick RJ (1978) The hydrogeology of the Magnesian Limestones in Yorkshire between the River Wharfe and the River Aire. Quart J Engineer Geol Hydrogeol 11(2):193-201

Allen DJ, Brewerton LM, Coleby BR, Gibbs MA, Lewis A, MacDonald SJ, Wagstaff AT, Williams LJ (1997) The physical properties of major aquifers in England and Wales. Technical Report WD/97/ 34, 157-287. British Geological Survey, Nottingham, England (UK)

Allen DJ, Bloomfield JP, Gibbs BR, Wagstaff SJ, (1998) Fracturing and the hydrogeology of the Permo-Triassic sandstones in England and Wales. Technical Report 97/34, 1-89. BGS, Nottingham, Engalnd (UK)

Allimendinger RW, Cardozo N, Fisher D (2012) Structural geology algorithms: vectors and tensors. Cambridge University Press, Cambridge

Amoruso A, Crescentini L, Petitta M, Tallini M (2013) Parsimonious recharge/discharge modeling in carbonate fractured aquifers: the groundwater flow in the Gran Sasso aquifer (Central Italy). J Hydrol 476:136-146

Bagherzadeh S, Kalantari N, Nobandegani AF, Derakhshan Z, Conti GO, Ferrante M, Malekahmadi R (2018) Groundwater vulnerability assessment in karstic aquifers using COP method. Environ Sci Pollut Res (19): 1-20

Bales RC, Gerba CP, Grondin GH, Jensen SL (1989) Bacteriophage transport in sandy soil and fractured tuff. Appl Environ Microbiol 55(8):2061-2067

Banks D, Davies C, Davies W (1995) The chalk as a karstic aquifer: evidence from a tracer test at Stanford Dingley, Berkshire, UK. Quart J Engineer Geol Hydrogeol 28:S31-S38

Barberio MD, Barbieri M, Billi A, Doglioni C, Petitta M (2017) Hydrogeochemical changes before and during the 2016 AmatriceNorcia seismic sequence (Central Italy). Sci Report 7(1):11735
Bauer S, Liedl R, Sauter M (2003) Modeling of karst aquifer genesis: influence of exchange flow. Water Resour Res 39(10). https://doi. org/10.1029/2003WR002218

Bauer H, Schröckenfuchs TC, Decker K (2016) Hydrogeological properties of fault zones in a karstified carbonate aquifer (Northern Calcareous Alps, Austria). Hydrogeol J 24:1147-1170

Berkowitz B (2002) Characterizing flow and transport in fractured geological media: a review. Adv Water Resour 25:861-884

Berkowitz B, Bear J, Braester C (1988) Continuum models for contaminant transport in fractured porous formations. Water Resour Res 24(8):1225-1236

Bicalho CC, Batiot-Guilhe C, Seidel JL, Van Exter S, Jourde H (2012) Geochemical evidence of water source characterization and hydrodynamic responses in a karst aquifer. J Hydrol 450:206-218

Billi A, Valle A, Brilli M, Faccenna C, Funiciello R (2007) Fracturecontrolled fluid circulation and dissolutional weathering in sinkhole-prone carbonate rocks from Central Italy. J Struct Geol 29(3):385-395

Boddy C (2018) Hydraulic characterization of the Cadeby Formation in the Tadcaster area (Yorkshire, NE England). MSc Thesis, University of Leeds (UK)

Bottrell SH, West LJ, Yoshida K (2006) Combined isotopic and modelling approach to determine the source of saline groundwaters in the Selby Triassic sandstone aquifer, UK. In: Barker, R.D., Tellam, J.H. (Eds.), Fluid flow and solute movement in sandstones: the onshore UK Permo-Triassic red bed sequence. Geol Soc Lond Spec Publ 263:325-338

Boulton NS (1970) Analysis of data from pumping tests in unconfined anisotropic aquifers. J Hydrol 10:369-378

Bredehoeft J, King M (2010) Potential contaminant transport in the regional carbonate aquifer beneath Yucca Mountain, Nevada, USA. Hydrogeol J 18(3):775-789

Burley SD (1984) Patterns of diagenesis in the Sherwood Sandstone Group (Triassic), United Kingdom. Clay Miner 19(3):403-440

Cairney T (1972) Hydrological investigation of the Magnesian Limestone of south-east Durham, England. J Hydrol 16(4):323-340

Conboy MJ, Goss MJ (2000) Natural protection of groundwater against bacteria of fecal origin. J Contam Hydrol 43(1):1-24

Cooper AH (1988) Subsidence resulting from the dissolution of Permian gypsum in the Ripon area; its relevance to mining and water abstraction. Geol Soc London Engineer Geol Spec Publ 5(1):387-390

Cooper AH, Lawley RS (2007) Tadcaster Magnesian Limestone 3-D borehole interpretation and cross-sections study. British Geological Survey, Nottingham

Crabtree RW, Trudgill ST (1984) Hydrochemical budgets for a magnesian limestone catchment in lowland England. J Hydrol 74(1-2):6779

Ducci D, Della Morte R, Mottola A, Onorati G, Pugliano G (2017) Nitrate trends in groundwater of the Campania region (southern Italy). Environ Sci Pollut Res 1-12(3):2120-2131

Edmunds WM, Shand P, Hart P, Ward RS (2003) The natural (baseline) quality of groundwater: a UK pilot study. Sci Total Environ 310(13):25-35

Environment Agency (2009) Magnesian Limestone-Tadcaster, water balance and modelling. REPORT 2008s3079. Environment Agency, Leeds

Falcone RA, Falgiani A, Parisse B, Petitta M, Spizzico M, Tallini M (2008) Chemical and isotopic $(\delta 18 \mathrm{O} \%$, $\delta 2 \mathrm{H} \%$ o, $\delta 13 \mathrm{C} \%$, $222 \mathrm{Rn})$ multi-tracing for groundwater conceptual model of carbonate aquifer (Gran Sasso INFN underground laboratory-Central Italy). J Hydrol 357(3-4):368-388

Farrant AR, Cooper AH (2008) Karst geohazards in the UK: the use of digital data for hazard management. Quart J Engineer Geol Hydrogeol 41(3):339-356 
Galdenzi S, Menichetti M (1995) Occurrence of hypogenic caves in a karst region: examples from Central Italy. Environ Geol 26(1):3947

Gallegos JJ, Hu BX, Davis H (2013) Simulating flow in karst aquifers at laboratory and sub-regional scales using MODFLOW-CFP. Hydrogeol J 21(8):1749-1760

Gárfias J, Llanos H, Martel R, Salas-García J, Bibiano-Cruz L (2018) Assessment of vulnerability and control measures to protect the Salbarua ecosystem from hypothetical spill sites. Environ Sci Pollut Res 25(26):26228-26245

Gaunt GD, Coope GR, Franks JW (1970) Quaternary deposits at Oxbow opencast coal site in the Aire Valley, Yorkshire. Proceed York Geol Soc 38(2): 175-200

Gillespie PA, Walsh JJ, Watterson J, Bonson CG, Manzocchi T (2001) Scaling relationships of joint and vein arrays from the Burren, Co. Clare, Ireland. J Struct Geol 23(2):183-201

Göppert N, Goldscheider N (2008) Solute and colloid transport in karst conduits under low-and high-flow conditions. Groundwater 46:6168

Gulley JD, Martin JB, Moore PJ, Brown A, Spellman PD, Ezell J (2015) Heterogeneous distributions of $\mathrm{CO}_{2}$ may be more important for dissolution and karstification in coastal eogenetic limestone than mixing dissolution. Earth Surf Process Landf 40(8):1057-1071

Hallam A (1971) Mesozoic geology and the opening of the North Atlantic. J Geol 79(2):129-157

Hartmann A, Goldscheider N, Wagener T, Lange J, Weiler M (2014) Karst water resources in a changing world: review of hydrological modeling approaches. Rev Geophys 52(3):218-242

Harwood GM (1986) The diagenetic history of Cadeby Formation carbonate (EZ1 Ca), Upper Permian, eastern England. Geol Soc Lond Spec Publ 22(1):75-86

Harwood GM, Coleman ML (1983) Isotopic evidence for UK Upper Permian mineralization by bacterial reduction of evaporites. Nature 301(5901):597-599

Hill ME, Stewart MT, Martin A (2010) Evaluation of the MODFLOW2005 conduit flow process. Groundwater 48(4):549-559

Hitchmough AM, Riley MS, Herbert AW, Tellam JH (2007) Estimating the hydraulic properties of the fracture network in a sandstone aquifer. J Contam Hydrol 93(1):38-57

Holden J, Grayson RP, Berdeni D, Bird S, Chapman PJ, Edmondson JL, Firbank LG, Helgason T, Hodson ME, Hunt SFP, Jones DT (2019) The role of hedgerows in soil functioning within agricultural landscapes. Agric Ecosyst Environ 273:1-12

Jones RB, Brouwers LB, Van Tonder LB, Dippenaar MA (2017) Assessing geotechnical centrifuge modelling in addressing variably saturated flow in soil and fractured rock. Environ Sci Pollut Res 24(15):13203-13223

Kaldi J (1986) Diagenesis of nearshore carbonate rocks in the Sprotbrough Member of the Cadeby (Magnesian Limestone) Formation (Upper Permian) of eastern England. Geol Soc Lond Spec Publ 22(1):87-102

Keim DM, West LJ, Odling NE (2012) Convergent flow in unsaturated fractured chalk. Vadose Zone J 11(4). https://doi.org/10.2136/ vzj2011.0146

Kocabas I, Bulbul M (2015) Modeling solute/contaminant transport in heterogeneous aquifers. Environ Sci Pollut Res 22(5):3298-3313

Kortas L, Younger PL (2013) Fracture patterns in the Permian Magnesian Limestone aquifer, Co. Durham, UK. Proceed York Geol Soc 59(3): $161-171$

Liu R, Zhang Z, Shen J, Wang Z (2018) Analysis of metal content and vertical stratification of epiphytic mosses along a karst mountain highway. Environ Sci Pollut Res 25(29):29605-29613

Lo HC, Chen PJ, Chou PY, Hsu SM (2014) The combined use of heatpulse flowmeter logging and packer testing for transmissive fracture recognition. J Appl Geophys 105:248-258
Lott G (2013) Sourcing stone for the conservation and repair of historical buildings in Britain. Q J Eng Geol Hydrogeol 46(4):405-420

Lott GK, Cooper AH (2005) The building limestones of the Upper Permian, Cadeby Formation (Magnesian Limestone) of Yorkshire. Report IR/05/048. British Geological Survey, Nottingham

Lott GK, Richardson C (1997) Yorkshire stone for building the Houses of Parliament (1839-c. 1852). Proceed York Geol Polytech Soc 51(4): 265-272

Maldaner CH, Quinn PM, Cherry JA, Parker BL (2018) Improving estimates of groundwater velocity in a fractured rock borehole using hydraulic and tracer dilution methods. J Contam Hydrol 214:75-86

Marijić VF, Kapetanović D, Dragun Z, Valić D, Krasnići N, Redžović Z, Grgić I, Žunić J, Kružlicová D, Nemeček P, Ivanković D (2018) Influence of technological and municipal wastewaters on vulnerable karst riverine system, Krka River in Croatia. Environ Sci Pollut Res 25(5):4715-4727

Maurice LAR, Robertson DW, Knight TL, Johns F, Edwards M, Arietti M, Sorensen JPR, Weitowitz D, Marchant BP, Bloomfield JP (2016) The invertebrate ecology of the chalk aquifer in England (UK). Hydrogeol J 24(2):459-474

Mayes WM, Large ARG, Younger PL (2005) The impact of pumped water from a de-watered magnesian limestone quarry on an adjacent wetland: Thrislington, County Durham, UK. Environ Pollut 138(3): 443-454

Medici G, Boulesteix K, Mountney NP, West L, Odling NE (2015) Palaeoenvironment of braided fluvial systems in different tectonic realms of the Triassic Sherwood Sandstone Group, UK. Sediment Geol 329:188-210

Medici G, West LJ, Mountney NP (2016) Characterizing flow pathways in a sandstone aquifer: tectonic vs sedimentary heterogeneities. J Contam Hydrol 194:36-58

Medici G, West LJ, Mountney NP (2018) Characterization of a fluvial aquifer at a range of depths and scales: the Triassic St Bees Sandstone Formation, Cumbria, UK. Hydrogeol J 26(2):565-591

Medici G, West LJ, Banwart SA (2019a) Groundwater flow velocities in a fractured carbonate aquifer-type: implications for contaminant transport. J Contam Hydrol 222:1-16. https://doi.org/10.1016/j. jconhyd.2019.02.001

Medici G, West LJ, Mountney NP (2019b) Sedimentary flow heterogeneities in the Triassic UK Sherwood Sandstone aquifer: insights for hydrocarbon exploration. Geol J 54(3):1361-1378

Mondal PK, Sleep BE (2013) Virus and virus-sized microsphere transport in a dolomite rock fracture. Water Resour Res 49(2):808-824

Mudarra M, Andreo B (2011) Relative importance of the saturated and the unsaturated zones in the hydrogeological functioning of karst aquifers: the case of Alta Cadena (southern Spain). J Hydrol 397(3-4):263-280

Murphy PJ (2000) The karstification of the Permian strata east of Leeds. Proceed York Geol Soc 53(1):25-30

Neymeyer ART, Williams PL, Younger PL (2007) Migration of polluted mine water in a public supply aquifer. Quart J Engineer Geol Hydrogeol 40(1):75-84

Odling NE, Gillespie P, Bourgine B, Castaing C, Chiles JP, Christensen NP, Fillion E, Genter A, Olsen C, Thrane L, Trice R (1999) Variations in fracture system geometry and their implications for fluid flow in fractured hydrocarbon reservoirs. Pet Geosci 1999 5(4):373-384

Odling NE, West LJ, Hartmann S, Kilpatrick A (2013) Fractional flow in fractured chalk; a flow and tracer test revisited. J Contam Hydrol 147:96-111

Palmucci W, Rusi S, Di Curzio D (2016) Mobilisation processes responsible for iron and manganese contamination of groundwater in Central Adriatic Italy. Environ Sci Pollut Res 23:11790-11805

Parkhurst DL, Appelo CAJ (1999) User's guide to PHREEQC - a computer program for speciation, batch reaction, one-dimensional transport and inverse geochemical calculations. United States Geological 
Survey, Water Resources Investigations. Report 95-4259. Denver, Colorado (USA)

Pekdeger A, Matthess G (1983) Factors of bacteria and virus transport in groundwater. Environ Geol 5(2):49-45

Perriquet M, Leonardi V, Henry T, Jourde H (2014) Saltwater wedge variation in a non-anthropogenic coastal karst aquifer influenced by a strong tidal range (Burren, Ireland). J Hydrol 519:2350-2365

Peryt TM, Scholle PA (1996) Regional setting and role of meteoric water in dolomite formation and diagenesis in an evaporite basin: studies in the Zechstein (Permian) deposits of Poland. Sedimentology 43(6): $1005-1023$

Petitta M, Fracchiolla D, Aravena R, Barbieri M (2009) Application of isotopic and geochemical tools for the evaluation of nitrogen cycling in an agricultural basin, the Fucino Plain, Central Italy. J Hydrol 372: 124-135

Petitta M, Mastrorillo L, Preziosi E, Banzato F, Barberio MD, Billi A, Cambi C, De Luca G, Di Carlo G, Di Curzio D, Di Salvo C (2018) Water-table and discharge changes associated with the 2016-2017 seismic sequence in Central Italy: hydrogeological data and a conceptual model for fractured carbonate aquifers. Hydrogeol J:1-18

Petrella E, Capuano P, Celico F (2007) Unusual behaviour of epikarst in the Acqua dei Faggi carbonate aquifer (southern Italy). Terra Nova 19(1):82-88

Piper AM (1953) A graphic procedure in the geochemical interpretation of water analysis. Groundwater Note 12. United States Geological Survey, Reston

Pollock DW (2016) User guide for MODPATH version 7 - a particletracking model for MODFLOW. United States Geological Survey, Report 2016-1086. Reston, Virginia (USA)

Quinn PM, Cherry JA, Parker BL (2011) Quantification of non-Darcian flow observed during packer testing in fractured sedimentary rock. Water Resour Res 47(9). https://doi.org/10.1029/2010WR009681

Railsback LB (1993) Lithologic controls on morphology of pressure-dissolution surfaces (stylolites and dissolution seams) in Paleozoic carbonate rocks from the mideastern United States. J Sediment Res 63(3):513-522

Rayne TW, Bradbury KR, Muldoon MA (2001) Delineation of capture zones for municipal wells in fractured dolomite, Sturgeon Bay, Wisconsin, USA. Hydrogeol J 9(5):432-450

Reh R, Licha T, Nödler K, Geyer T, Sauter M (2015) Evaluation and application of organic micro-pollutants (OMPs) as indicators in karst system characterization. Environ Sci Pollut Res 22:4631-4643

Ren S, Gragg S, Zhang Y, Carr B, Yap G (2018) Borehole characterization of hydraulic properties and groundwater flow in a crystalline fractured aquifer of a headwater mountain watershed, Laramie Range, Wyoming. J Hydrol 561:780-795

Riva M, Guadagnini A, De Simoni M (2005) Assessment of uncertainty associated with the estimation of well catchments by moment equations. Adv Water Resour 29:676-691

Rivett MO, Smith JWN, Buss SR, Morgan P (2007) Nitrate occurrence and attenuation in the major aquifers of England and Wales. Quart J Engineer Geol Hydrogeol 40(4):335-352

Rivett MO, Buss SR, Morgan P, Smith JW, Bemment CD (2008) Nitrate attenuation in groundwater: a review of biogeochemical controlling processes. Water Res 42(16):4215-4232

Saller SP, Ronayne MJ, Long AJ (2013) Comparison of a karst groundwater model with and without discrete conduit flow. Hydrogeol $\mathrm{J}$ 21(7):1555-1566

Smith DB, Harwood GM, Pattison J, Pettigrew TH (1986) A revised nomenclature for Upper Permian strata in eastern England, in:
Harwood, G.M., Smith D.B. (Eds.), The English Zechstein and related topics. Geol Soc Lond Spec Publ 22(1):9-17

Talling JF (2006) Interrelated seasonal shifts in acid-base and oxidationreduction systems that determine chemical stratification in three dissimilar English Lake Basins. Hydrobiologia 568(1):275-286

Taylor R, Cronin A, Pedley S, Barker J, Atkinson T (2004) The implications of groundwater velocity variations on microbial transport and wellhead protection-review of field evidence. FEMS Microbiol Ecol 49(1):17-26

Tondi E, Antonellini M, Aydin A, Marchegiani L, Cello G (2006) The role of deformation bands, stylolites and sheared stylolites in fault development in carbonate grainstones of Majella Mountain, Italy. J Struct Geol 28(3):376-391

Wakida FT, Lerner DN (2005) Non-agricultural sources of groundwater nitrate: a review and case study. Water Res 39(1):3-16

Walker CD (2006) A physical and hydrochemical investigation of the Magnesian Limestone in the Tadcaster area, North Yorkshire. MSc Thesis, University of Leeds (UK)

Walsh JJ, Watterson J (1988) Dips of normal faults in British Coal Measures and other sedimentary sequences. J Geol Soc 145(5): 859-873

West LJ, Odling NE (2007) Characterization of a multilayer aquifer using open well dilution tests. Groundwater 45(1):4-84

West LJ, Truss SW (2006) Borehole time domain reflectometry in layered sandstone: impact of measurement technique on vadose zone process identification. J Hydrol 319(1):143-162

Woodcock NH, Mort K (2008) Classification of fault breccias and related fault rocks. Geol Mag 145(3):435-440

Worthington SRH, Ford DC (2009) Self-organized permeability in carbonate aquifers. Groundwater 47(3):326-336

Worthington SR, Smart CC, Ruland W (2012) Effective porosity of a carbonate aquifer with bacterial contamination: Walkerton, Ontario, Canada. J Hydrol 464:517-527

Xanke J, Goeppert N, Sawarieh A, Liesch T, Kinger J, Ali W, Hötzl H, Hadidi K, Goldscheider N (2015) Impact of managed aquifer recharge on the chemical and isotopic composition of a karst aquifer, Wala reservoir, Jordan. Hydrogeol J 23(5):1027-1040

Yager RM, Plummer LN, Kauffman LJ, Doctor DH, Nelms DL, Schlosser P (2013) Comparison of age distributions estimated from environmental tracers by using binary-dilution and numerical models of fractured and folded karst: Shenandoah Valley of Virginia and West Virginia, USA. Hydrogeol J 21(6):1193-1217

Yang S, Wu Z, Lin W, Xu L, Cheng L, Zhou L (2017) Investigations into Salmonella contamination in feed production chain in karst rural areas of China. Environ Sci Pollut Res 24(2):1372-1379

Younger PL (1995) Hydrogeochemistry of minewaters flowing from abandoned coal workings in County Durham. Q J Eng Geol 28(2): $101-113$

Zhang X, Li X, Gao X (2016) Hydrochemistry and coal mining activity induced karst water quality degradation in the Niangziguan karst water system, China. Environ Sci Pollut Res 23(7):6286-6299

Zuffianò LE, Basso A, Casarano D, Dragone V, Limoni PP, Romanazzi A, Santaloia PM (2016) Coastal hydrogeological system of Mar Piccolo (Taranto, Italy). Environ Sci Pollut Res 23(13):1250212514

Publisher's note Springer Nature remains neutral with regard to jurisdictional claims in published maps and institutional affiliations. 